Kristina Matic *

Kristina Petljak ${ }^{* *}$

Ivana Štulec ${ }^{* * *}$
JEL Classification L81

Prethodno priopćenje

https://doi.org/10.32910/ep.70.2.7

\title{
PRIHVAĆENOST SAMOPOSLUŽNIH BLAGAJNI PRILIKOM KUPOVINE ROBE ŠIROKE POTROŠNJE MEĐU MLADIM POTROŠAČIMA U HRVATSKOJ
}

Razvoj informacijskih i komunikacijskih tehnologija uzrokuje velike promjene na maloprodajnom tržištu. Kako bi išli u korak sa konkurencijom, maloprodavači su prisiljeni uvoditi inovacije, kako u asortiman tako i u način posluživanja, dostavu i naplatu kupovine. Tu se javlja prostor, a i potreba za uvođenjem tehnoloških inovacija poput samoposlužne tehnologije u maloprodajni poslovni proces. Zbog užurbanog načina života, potrošači danas imaju sve manje vremena za kupovinu, a tijekom kupovine zahtijevaju sve više informacija o proizvodima koje kupuju te su voljni što manje čekati na blagajnama. Upravo stoga glavni su motivi za uvođenje samoposlužne tehnologije u prodavaonice pružiti kupcima veći izbor usluga te omogućiti jednostavniju i bržu kupovinu. Najrasprostranjeniji oblik samoposlužne tehnologije unutar prodavaonice su samoposlužne blagajne. Samoposlužna blagajna je blagajna na kojoj potrošači sami skeniraju proizvode koje su izabrali, spreme ih u vrećice te sami plate račun. Svrha je rada istražiti prihvaćenost samoposlužnih blagajni prilikom kupovine robe široke potrošnje među mladim potrošačima u Hrvatskoj. S ciljem otkrivanja prihvaćenosti samoposlužnih blagajni prilikom kupovine od strane mladih hrvatskih potro-

${ }^{*}$ Kristina Matić , mag. oec., studentica, Sveučilište u Zagrebu, Ekonomski fakultet Zagreb.

** Dr. sc. K. Petljak, docentica, Sveučilište u Zagrebu, Ekonomski fakultet Zagreb (E-mail: kpetljak@efzg.hr).

**** Dr. sc. I. Štulec, docentica, Sveučilište u Zagrebu, Ekonomski fakultet Zagreb (E-mail: istulec@efzg.hr).

Rad je primljen u uredništvo 09.09.2017. godine, a prihvaćen je za objavu 17.11.2018. 
šača, razloga (ne)korištenja samoposlužnih blagajni te prikupljanja ideja za moguća unaprjeđenja samoposlužnih blagajni na hrvatskom maloprodajnom tržištu provedeno je istraživanje metodom fokus grupe. Radi bolje usporedbe $i$ analize podataka ispitanici su bili podijeljeni u dvije fokus grupe - prvu su činili korisnici samoposlužne blagajne, dok su drugu fokus grupu činili nekorisnici samoposlužne blagajne. Pitanja oko kojih se raspravljalo na fokus grupi odnosila su se na: (1) osobnost $i$ tehnološku spremnost korisnika $i$ nekorisnika samoposlužne blagajne; (2) učestalost kupovine samoposlužnom blagajnom i način plaćanja; (3) sigurnost osobnih podataka; (4) tehničke pogreške; (5) percipirani utjecaj samoposlužnih blagajni na smanjenje prodajnog osoblja; (6) mogućnosti unaprjeđenja samoposlužne blagajne $i$ (7) poznavanje $i$ korištenje ostalih samoposlužnih tehnologija u maloprodaji. Rezultati istraživanja ukazuju da samoposlužna blagajna još uvijek nije u potpunosti prihvaćena od strane mladih hrvatskih potrošača te da se na nju gleda isključivo kao na pomoćnu blagajnu. Jedan od glavnih razloga neprihvaćenosti samoposlužne blagajne su učestale tehničke pogreške koje se javljaju prilikom njezina korištenja te se zaključuje da postoji veliki potencijal za unaprjeđenje rada samoposlužnih blagajni s ciljem povećanja prihvaćenosti maloprodajnih inovacija od strane potrošača. Glavno ograničenje provedenog istraživanja je ograničenje same istraživačke metode. S ciljem potpunijeg razumijevanja i ostvarivanja istraživačkih ciljeva, predlaže se u budućnosti provođenje kvantitativnog istraživanja u samim prodavaonicama koje imaju samoposlužne blagajne. Znanstveni doprinos $i$ vrijednost rada ogleda se $u$ dubinskom istraživanju i analizi prihvaćenosti samoposlužnih blagajni prilikom kupovine robe široke potrošnje među mladim potrošačima u Hrvatskoj.

Ključne riječi: maloprodaja, samoposlužna tehnologija, samoposlužne blagajne, korisnici samoposlužne blagajne, nekorisnici samoposlužne blagajne, mladi potrošači, fokus grupa.

\section{Uvod}

Intenzivna konkurencija, koja obilježava današnje maloprodajno tržište, maloprodavaču predstavlja sve složeniji i zahtjevniji zadatak zadržavanja postojećih i privlačenja novih potrošača. Maloprodavači u borbi za potrošače koriste razne maloprodajne strategije, a sve se više pri kreiranju novih usluga oslanjaju na tehnološke inovacije. Tehnološke inovacije su se u prošlosti pokazale kao važan pokretač pozitivnih promjena u trgovini pa ih tako vodeći maloprodavači nerijetko koriste za unapređenje poslovnih procesa, stvaranje prednosti u odnosu na konkurente te pružanje dodatnih usluga potrošačima (Guszak, Brčić-Stipčević i Vouk, 2011). 
Osim toga, uvođenje tehnologija u poslovni proces doprinosi smanjenju troškova te povećanju operativne učinkovitosti, a u konačnici i poboljšanju poslovnog rezultata. Primjer takvih tehnoloških inovacija su samoposlužne (engl. self-service) tehnologije. Samoposlužne tehnologije su tehnološka rješenja koja omogućavaju potrošačima korištenje usluga bez izravne podrške i pomoći prodajnog osoblja. U razvoju samoposlužnih tehnologija ključnu ulogu imala je sve veća primjena Interneta u poslovanju.

Danas postoji velik broj aktivnosti koje se realiziraju uz pomoć samoposlužnih tehnologija, primjerice poput samoposlužnih benzinskih crpki, bankomata, bezgotovinske naplate cestarina, studomata, m-parkinga i sličnih (Kokkinou i Cranage, 2015). Osim navedenih primjera, usluge temeljene na tehnološkim inovacijama ušle su i u mnoge druge industrije i sektore, pa između ostalog i u sektor maloprodaje. Budući da su potrošači danas spremni sve manje vremena provesti u kupovini, a za kratko vrijeme procesa kupnje zahtijevaju sve više informacija o proizvodima koje kupuju, glavni motivi za uvođenje samoposlužne tehnologije u prodavaonice su pružiti kupcima veći izbor usluga te omogućiti jednostavniju i bržu kupovinu (Guszak i sur., 2011).

Cilj je ovog rada dublje analizirati i istražiti (ne)prihvaćenost samoposlužnih blagajni prilikom kupovine robe široke potrošnje od strane mladih hrvatskih potrošača, razloge (ne)korištenja samoposlužnih blagajni te prikupiti ideje za moguća unaprjeđenja samoposlužnih blagajni na hrvatskom maloprodajnom tržištu. Sukladno predmetu i cilju istraživanja, određena je i struktura ovoga rada. Nakon teorijskog osvrta na važnost i značaj samoposlužne tehnologije, daje se pregled postojećih stranih i domaćih istraživanja o (ne) prihvaćenosti samoposlužnih tehnologija prilikom kupovine. Nadalje se u radu opisuju dva istraživanja provedena metodom fokus grupe, i to sa korisnicima i nekorisnicima samoposlužnih blagajni u Republici Hrvatskoj. Potom se u radu uspoređuju stavovi korisnika i nekorisnika samoposlužne blagajne, te se kompariraju rezultati istraživanja provedenog u Hrvatskoj sa rezultatima prijašnjih istraživanja. U radu se navode ograničenja istraživanja i preporuke za buduća istraživanja. Rad završava zaključkom.

\section{Samoposlužna tehnologija}

\subsection{Definiranje samoposlužne tehnologije}

Jedan od ključnih oblika tehnologije primijenjene u maloprodaji je koncept samo-usluge (eng. self-sevice), a radi se o tehnologiji koja potrošačima omogućava samostalno obavljanje kupovine bez direktne interakcije sa zaposlenicima koja po- 
trošaču omogućuje drugačiji doživljaj kupovine. Maloprodavačima u ovom slučaju nije jedini cilj automatizacijom nadomjestiti prodajno osoblje nego i pribaviti više informacija o potrošačima te ubrzati obračun i plaćanje (Dunković i Brozović, 2011). U prodavaonicama najrasprostranjeniji oblici samoposlužne tehnologije su samoposlužne blagajne i prijenosni skeneri.

Samoposlužna blagajna je aparat na kojem kupci sami skeniraju proizvode koje su izabrali, spreme ih u vrećice i sami plate račun. U cjelokupan proces kupovine prodajno osoblje gotovo da i nije uključeno no ukoliko potrošači zatrebaju pomoć prilikom korištenja samoposlužne blagajne na raspolaganju im je jedan od prodajnih asistenata koji nadziru blagajne. Cijena jedne samoposlužne blagajne iznosi oko 20.000 dolara, a povrat investicije može se očekivati za godinu i sedam mjeseci. U svjetski poznatim maloprodajnim lancima poput Tesco-a ili Sainsburyj-a, $50 \%$ naplatnih mjesta čine samoposlužne blagajne (Žujo, 2012). Prema istraživanju objavljenom od strane globalne istraživačke kuće RBR, počevši od 2008. godine, kada je broj globalno rasprostranjenih samoposlužnih blagajni iznosio 90000 pa do 2011. godine kada ih je bilo 166 800, godišnji rast iznosio je 25\%. Za 2015. godinu prognoziralo se da će se taj broj udvostručiti, te iznositi 381800 (NCR, 2014). Slika 1. prikazuje rast broja instaliranih samoposlužnih blagajni u svijetu.

\section{Slika 1.}

\section{BROJ INSTALIRANIH SAMOPOSLUŽNIH BLAGAJNI U SVIJETU}

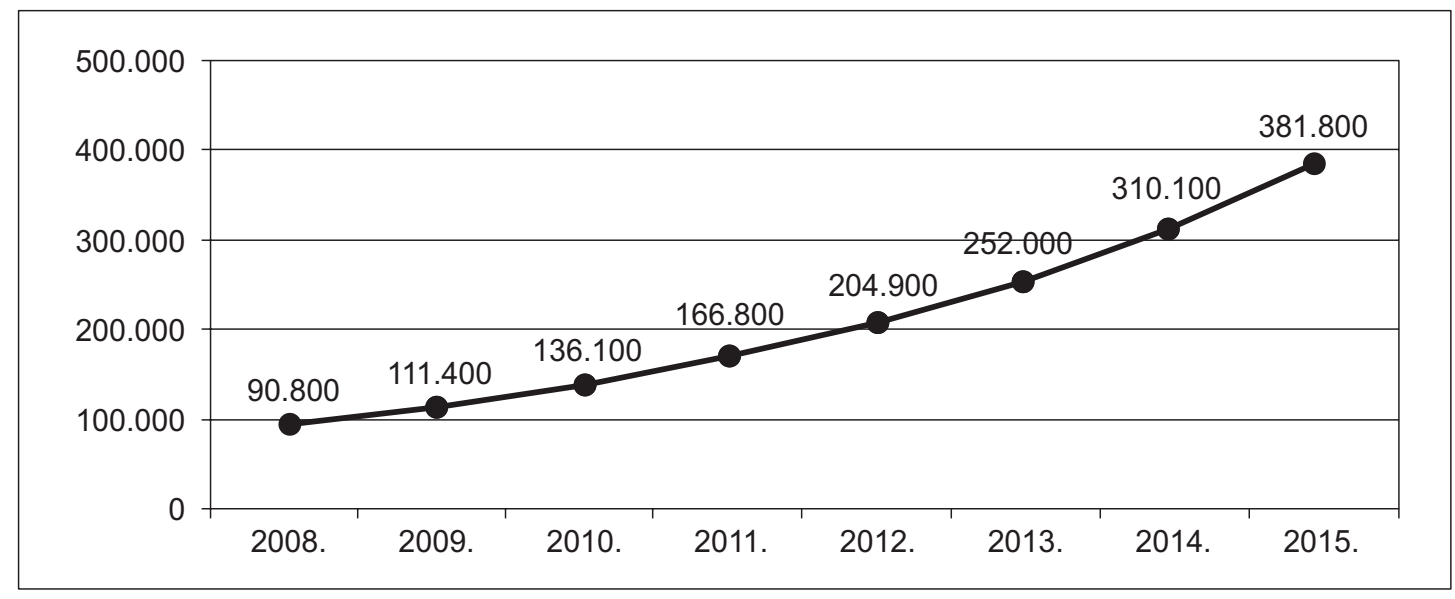

Izvor: vlastita obrada, prema NV-INCO (2013) 
Osim samoposlužne blagajne postoje još mnogi oblici samoposlužnih tehnologija unutar prodavaonice koji su manje razvijeni na domaćem tržištu ili ih uopće nema. Sustav prijenosnih skenera temelji se na skeneru, prijenosnom aparatu, koji kupci nose sa sobom dok obilaze prodavaonicu i koriste ga za skeniranje proizvoda kako ih izabiru s polica. Kad završe kupnju, kupci skener predaju na mjestu naplate zaposleniku prodavaonice, koji izvrši naplatu, ili mogu sami platiti na kiosku za samostalnu naplatu (Guszak i sur., 2011). Primjena prijenosnih skenera započela je u Njemačkoj i Italiji (Dunković, Ružić i Jurić, 2010). Osobni asistent za kupovinu (engl. Personal Shopping Assistant-PSA) je uređaj koji se postavlja na kolica za kupovinu kako bi potrošaču omogućio dobivanje informacija o proizvodima, posebnim ponudama, te cijeni proizvoda prije njegovog stavljanja u kolica. Uređaj se sastoji od ekrana na dodir i čitača bar-koda, a sa središnjim sustavom povezan je bežičnom Internet vezom. Najznačajnija je prednost ovoga sustava automatsko očitavanje sadržaja kolica na izlasku iz prodavaonice. Radiofrekvencijska identifikacija (engl. radio frequency identification - RFID) - koncept prodavaonice opremljene RFID infrastrukturom zamišljen je tako da su kupcu u svakom trenutku dostupne sve potrebne informacije o kupnji, a to je omogućeno putem mobilnog ekrana koji se nalazi na kolicima. Mobilni uređaj vodi kupca kroz prodavaonicu najkraćim putem do cilja i daje podatke o željenom proizvodu. Mobilni uređaj prepoznaje kupca, podsjeća ga na raniju kupovinu koju ima u svojoj memoriji i tako pomaže pri izboru artikala. Nakon odabira proizvoda s polica prodavaonice potrošač ih stavlja u košaricu i odlazi do automatiziranih mjesta za naplatu gdje se svi proizvodi skeniraju istodobno.

Nove tehnologije u maloprodaji unutar prodavaonice najprije su prihvatili i primijenili veliki maloprodajni formati, kakvi su hipermarketi i supermarketi, što nije začuđujuće s obzirom da $80 \%$ troškova rada u tim maloprodajnim formatima nastaje upravo na blagajni. Maloprodavači izbjegavaju spominjanje smanjenja troška radne snage kao motiva za uvođenje samoposlužnih tehnologija, međutim u konačnici rado prihvaćaju taj efekt, a i s time povezane i manje troškove. Smanjenje potrebe za radnom snagom rezultira preraspodjelom posla među prodajnim osobljem, koji umjesto rada na blagajnama pružaju dodatne usluge kupcima, poput pružanja dodatnih informacija o proizvodima i savjeta za kupovinu. Sve spomenute aktivnosti rezultiraju ponudom dodatnih usluga za potrošače te unapređenjem doživljaja kupovine kako bi potrošači u konačnici bili zadovoljni. Dodatne koristi za maloprodavače su rast plaćanja karticama i manje manipulacije gotovinom (Guszak i sur., 2011). Uz pozitivne učinke, za uvođenje samoposlužnih tehnologija pojavljuju se i izazovi. Najveći potencijalni problem vezan uz samoposlužne tehnologije je pitanje sigurnosti, odnosno, kako spriječiti da proizvodi izađu iz prodavaonice bez plaćanja. Sustavi prevencije uključuju primjenu digitalnih vaga na samoposlužnim blagajnama, uz pomoću kojih zaposlenici nadziru upotrebu samoposlužnih tehnologija (digitalne vage na odjelu za povrće i voće), te nasumične 
kontrole skeniranih proizvoda, pri kojima je kupovina svakog n-tog proizvoda ponovno skenirana odnosno provjerena. Još jedan problem vezan je uz kontrolu prodaje alkoholnih pića maloljetnicima, a osim toga maloprodavači moraju osmisliti i učinkoviti sustav uklanjanja sigurnosnih zaštita s proizvoda (Guszak i sur., 2011).

Uspješnost maloprodavača i proizvođača samoposlužnih tehnologija u prevladavanju ovih izazova potvrđuju ostvarene koristi koje su veće od troškova te se tako vrijeme potrebno za povrat uloženih sredstava u investiciju (engl. Return on investment - ROI) kreće između jedne i dvije godine. Rast produktivnost poduzeća proizlazi iz veće produktivnosti rada koja se bazira na preraspodjeli poslova te iz veće razine usluga potrošačima. Primjena samoposlužnih tehnologija u prodavaonicama je uspješna i zbog velike popularnosti samoposlužnih blagajni i prijenosnih skenera kod potrošača, koji nove usluge vrlo brzo prihvaćaju (Guszak i sur., 2011). Još od uvođenja samoposlužnih tehnologija istraživanja su naglašavala vrijednost tehnologije i koristi od potrošača kao djelomičnih radnika iz perspektive učinkovitosti i smanjenja troškova. Danas je taj pojam dobro uspostavljen u nizu istraživačkih disciplina, od informacijskih sustava za upravljanje do menadžmenta te primjene u marketingu (Scherer, Wünderlich i Wangenheim, 2015).

\subsection{Primjena samoposlužne tehnologije na hrvatskom maloprodajnom tržišštu}

Nagli ulazak stranih maloprodajnih lanaca na domaće tržište početak je suvremenog razvoja maloprodajne strukture u Hrvatskoj. Osim uvođenja novih maloprodajnih oblika prodavaonica to je rezultiralo i uvođenjem tehnoloških dostignuća na hrvatsko maloprodajno tržište (Dunković i sur., 2010). Mogućnost primjene automatiziranih sustava na hrvatskom tržištu vrlo je oskudna (Dunković i Brozović, 2011). Od samoposlužne tehnologije unutar prodavaonica na hrvatskom maloprodajnom tržištu koriste se samoposlužne blagajne i prijenosni skeneri.

U Hrvatskoj se prva samoposlužna blagajna pojavila krajem 2007. godine u Rijeci. U sljedećoj fazi uvođenja implementirane su u prodavaonice u Puli, Splitu, Zadru i Zagrebu. Posebnost uvođenja samoposlužnih blagajni na hrvatsko tržište je podatak da je za te potrebe po prvi puta sustav razvijen za nacionalnu valutu male države poput Hrvatske. U procesu uvođenja samoposlužnih blagajni nisu korištene posebne inicijative za privlačenje potrošača novoj usluzi samostalnog skeniranja i plaćanja proizvoda. Potrošači su vrlo brzo prepoznali ključne prednosti nove tehnologije i prihvatili novu uslugu. Oko 35\% transakcija u prodavaonicama koje nude samoposlužne blagajne se odvija upravo putem nove tehnologije (Guszak i sur., 2011). 
Sustavi prijenosnih skenera su se u Hrvatskoj u prvoj prodavaonici pojavili u ljeto 2010. godine. Informiranje, privlačenje i edukacija potrošača o novoj usluzi i novoj tehnologiji su bili sastavni elementi projekta implementacije. Šest mjeseci nakon uvođenja, sustav je u potpunosti integriran i ostvarena je bolja učinkovitost i produktivnost, niži troškovi poslovanja te je unaprijeđena usluga potrošačima. Pristup se pokazao izuzetno uspješnim, jer 75\% potrošača koji su bili educirani u prvoj fazi projekta redovito koristi prijenosne skenere kad kupuje u prodavaonici s tom uslugom. Istraživanje provedeno od veljače do kolovoza 2011. godine pokazalo je da je u Hrvatskoj u funkciji 56 samoposlužnih blagajni i 32 prijenosna skenera (Guszak i sur., 2011).

Mogućnost kupovine uz pomoć samoposlužne blagajne imaju dva maloprodajna lanca Konzum i Plodine, a prijenosnim skenerom i online kupovinu robe široke potrošnje samo jedan maloprodajni lanac Konzum. Danas je Konzum u 24 svoja centra instalirao nešto više od stotinu samonaplatnih blagajni (Jatrgovac, 2016). Što se tiče maloprodajnog lanca Plodine, njihov hipermarket u Zapruđu potrošačima nudi mogućnost kupovine na četiri samoposlužne blagajne (Jatrgovac, 2011). Domaće tržište općenito nema kapaciteta niti dovoljne financijske moći kako bi moglo pratiti razvoj ili kopirati najnovije tehnološke inovacije. Međutim, unatoč tome kupci sve više prate razvoj tehnologije te očekuju mogućnost primjene novih tehnologija. Zbog toga razloga bi sudionike u domaćem sektoru trebalo ohrabrivati za uvođenje tehnoloških inovacija (Dunković i Brozović, 2011).

\section{Pregled postojećih istraživanja o (ne)prihvaćenosti samoposlužnih tehnologija prilikom kupovine}

Lee et al. (2010) istražuju odnose između demografskih obilježja (spol, dob, obrazovanje, godišnjih prihodi), osobina potrošača (potreba za komunikacijom, strah, nepovjerenje prema tehnologiji, tehnološka inovativnost) i namjere za korištenjem samoposlužnih blagajni. Istraživanje je provedeno u SAD-u putem online anketnog upitnika. U istraživanju je sudjelovalo 285 potrošača koji su se koristili samoposlužnom blagajnom u posljednjih 6 mjeseci. Autori su došli do zaključka da demografska obilježja i osobine potrošača ne utječu direktno na namjeru potrošača da se koriste samoposlužnim blagajnama, no osobine potrošača su određene demografskim obilježjima te predstavljaju varijable u izračunu namjere potrošača hoće li ili neće koristiti samoposlužne blagajne. Tako npr. stariji potrošači imaju veću potrebu za komunikacijom sa prodajnim osobljem nego mlađi potrošači te će se teže odlučiti na korištenje samoposlužne blagajne.

Dabholkar i Spaid (2012) su istraživali kako kvarovi i popravci samoposlužnih uređaja utječu na mišljenje potrošača o samoposlužnoj tehnologiji, o pruža- 
telju usluga i o zaposlenicima koji uklanjaju kvarove. Istraživanje je provedeno u SAD-u Internet anketom u kojoj je sudjelovalo 368 ispitanika. Anketa se provodila na način da su ispitanici prvo pročitali priču koja je opisivala iskustvo korištenja samoposlužne tehnologije te su nakon toga odgovarali na pitanja. Anketa se sastojala od 16 različitih situacija/priča koje su ispitanici mogli dobiti. Istraživanje je pokazalo da ako se problem ukloni u što kraćem vremenskom roku, manji su negativni efekti i nezadovoljstvo potrošača. Na veće zadovoljstvo potrošača utječe i okolina, što je okolina bila manje stresna to je zadovoljstvo potrošača prilikom korištenja samoposlužne tehnologije bilo veće. Na negativno mišljenje, odnosno nezadovoljstvo potrošača samoposlužnom tehnologijom su najviše utjecale tehničke pogreške kod samoposlužnih uređaja. Potrošači su također gledali pozitivno na zaposlenike kada bi im oni pomogli prilikom kvarova ili problema sa samoposlužnom tehnologijom, ali je to povećalo nezadovoljstvo potrošača prema samoposlužnoj tehnologiji.

Elliott, Meng i Hall (2013) su istraživali kako tehnološka spremnost (sklonosti potrošača da prihvate i koriste nove tehnologije da bi postigli osobne i poslovne ciljeve) potrošača utječe na njihovo mišljenje o pouzdanosti i zabavi kod korištenja samoposlužnih tehnologija. Također su istražili i kako tehnološka spremnost utječe na namjeru potrošača da koriste samoposlužne tehnologije. Istraživanje je provedeno putem online anketnog upitnika na uzorku od 1079 ispitanika u SAD-u. Autori su zaključili da tehnološka spremnost ima direktan pozitivan utjecaj na percepciju pouzdanosti i zabave za potrošače kod korištenja samoposlužne tehnologije, no ima jako mali utjecaj na odluku potrošača hoće li ili neće koristiti samoposlužne tehnologije.

NCR (2014) korporacija je provela istraživanje o stavovima potrošača vezanih uz samoposlužne blagajne. Istraživanje je provedeno globalno, anketnim upitnikom, a sudjelovalo je 2803 potrošača. Potrošači su rekli da samoposlužne blagajne koriste najčešće kad su žurbi, kad su redovi na tradicionalnim blagajnama predugi te kad kupuju malo proizvoda (najčešće manje od 15 proizvoda), a najviše im se sviđa praktičnost i jednostavnost samoposlužnih blagajni. Većina potrošača se složila s tvrdnjom da maloprodajne prodavaonice koje imaju samoposlužne blagajne pružaju bolju korisničku podršku. Potrošači su preporučili i poboljšanja koja bi se mogla napraviti da bi iskustvo prilikom kupovine na samoposlužnoj blagajni bilo bolje, a najviše potrošača je predložilo povećanje prostora za pakiranje proizvoda (45\%), te smatraju da bi im prodajno osoblje uvijek trebalo biti na raspolaganju za pomoć pri kupovini na samoposlužnoj blagajni. Na globalnoj razini je samo $10 \%$ potrošača izjavilo da se uopće ne koristi samoposlužnim blagajnama, a glavni razlog u 50\% slučajeva je da preferiraju pomoć zaposlenika na blagajnama za dodatna pitanja.

Åkesson, Edvardsson i Tronvoll (2014) proveli su istraživanje o tome kako se stvaraju, odnosno kako se formiraju dobra (pozitivna) i loša (negativna) iskustva 
potrošača u kupovini u svrhu identifikacije osnovnih pokretača potrošača kod korištenja samoposlužne tehnologije. Prilikom istraživanja su analizirali put potrošača prije, za vrijeme i nakon korištenja samoposlužnih tehnologija. Istraživanje je provedeno u prodavaonici IKEA-e u Švedskoj, gdje su autori napravili 60 opširnih intervjua sa potrošačima. Ispitanici koji su sudjelovali u istraživanju su morali koristiti barem dvije vrste samoposlužne tehnologije u zadnjih šest mjeseci. U istraživanju su se autori orijentirali na četiri vrste samoposlužnih tehnologija: 1. Internet alat i online vodič za izradu kuhinje prije dolaska u prodavaonicu, 2. aplikaciju za izradu liste za kupovinu, 3. brzu samoposlužnu blagajnu, 4. aplikaciju za pregled dostupnosti proizvoda u prodavaonici. Autori su identificirali 13 povoljnih i nepovoljnih pokretača te ih rasporedili u 4 kategorije, (informacijska, relacijska, organizacijska, tehnološka) koje utječu na formiranje pozitivnih odnosno negativnih iskustava kod korištenja samoposlužne tehnologije te su objasnili na što treba obratiti pozornost prilikom kreiranja samoposlužnih tehnologija. Neki od zaključaka do kojih su autori došli provodeći istraživanje su da potrošači vole kada se mogu informirati o proizvodima prije dolaska u prodavaonicu, zatim vole kontrolirati cijeli tijek kupovine, ne vole čekati u redovima, te žele raditi bilo što, makar to bilo nevažno samo da ne čekaju u redu i ne gube vrijeme. Tako npr. kada potrošač dobije informaciju o samoposlužnoj blagajni i odluči ju testirati, to mu pruža osjećaj kontrole. Prilikom korištenja samoposlužne blagajne, potrošač shvaća da ona nije komplicirana za korištenje te mu raste povjerenje prema prodavaonici u kojoj imam mogućnost kupovine samoposlužnom blagajnom.

Kokkinou i Cranage (2015) su istražili kako duljina reda čekanja utječe na odluku potrošača u odabiru između samoposlužne tehnologije i tradicionalne blagajne sa zaposlenikom. Istraživanje je provedeno putem online anketnog upitnika, a anketni upitnik je ispunilo 2239 osoba. Autori su zaključili da su potrošači motiviraniji koristiti samoposlužne tehnologije što je red na tradicionalnim blagajnama sa zaposlenicima duži. U prosjeku 70,54\% osoba odabire samoposlužnu tehnologiju kad je red na blagajni s prodajnim osobljem duži. Na odabir između samoposlužne tehnologije i tradicionalne blagajne, osim reda čekanja, utječu još neki faktori poput kvalitete samoposlužne tehnologije, potrebe potrošača za komunikacijom te nelagoda (strah) od korištenja tehnologije te i oni imaju snažan utjecaj na odluku potrošača hoće li koristiti samoposlužne tehnologije ili neće.

Guszak i sur. (2011) proveli su istraživanje o primjeni samoposlužnih tehnologija na tržištu proizvoda svakodnevne potrošnje u Hrvatskoj, Srbiji, Sloveniji i Bosni i Hercegovini. Istraživanje se bavilo utvrđivanjem zastupljenosti samoposlužnih tehnologija, izazovima vezanima uz primjenu novih tehnologija, očekivanom i ostvarenom koristi za kupce i poduzeća te motivima uvođenja samoposlužnih tehnologija. U svim spomenutim državama osim Bosne i Hercegovine, postoje poduzeća koja su implementirala samoposlužne tehnologije u svoje prodavaonice. Istraživanje je provedeno osobnom komunikacijom putem elektroničke 
pošte i dubinskim intervjuima sa predstavnicima poduzeća koja koriste neku vrstu samoposlužne tehnologije. Istraživanje je pokazalo da su poduzeća koja su uvela samoposlužne tehnologije ostvarila brojne koristi poput porasta učinkovitosti operacija, nižih troškova, veće produktivnosti rada, kraćih redova na blagajnama, veće protočnosti kupaca kroz prodavaonicu. Poduzeća koja su uvela samoposlužne tehnologije u svoje prodavaonice su lideri na domaćim tržištima te su uvođenjem samoposlužne tehnologije pružili kupcima dodatnu usluge i potvrdili uloge lidera na svojim tržištima. Također autori dolaze do zaključka da samoposlužne blagajne mogu dodatno poslužiti kao sredstvo ublažavanja sezonalnosti tj. opterećenja sustava naplate u prodavaonicama u turističkim područjima. Obzirom da samoposlužne blagajne omogućavaju veću protočnost unutar prodavaonice ublažavaju razlike u potrebi za radnom snagom za vrijeme i izvan turističke sezone, a s obzirom na višejezičnost stranim potrošačima pojednostavljuju kupovinu.

Kovač i Bajkovec (2015) su proveli istraživanje o percepciji i svijesti potrošača o inovacijama na hrvatskom maloprodajnom tržištu. Istraživanjem su autori htjeli doći do zaključka koje se inovacije na hrvatskom maloprodajnom tržištu koriste najviše, a koje najmanje. Istraživanje je provedeno u Hrvatskoj, anketirano je 304 potrošača različite dobi, razine obrazovanja i spola. Istraživanje je pokazalo da $65 \%$ potrošača vjeruje da korištenjem inovacija u maloprodaji mogu uštedjeti vrijeme. Kao najveće razloge zašto ne koriste inovacije u maloprodaji, odnosno koji su razlozi straha od korištenja tehnologije, potrošači su naveli ugroženost privatnosti (vlastitih privatnih podataka) i manjak sigurnosti, tj. mogućnost novčanog gubitka u slučaju npr. krađe podataka s kreditnih kartica. U istraživanju su autori došli i do zaključka da potrošači s višom razinom obrazovanja više koriste samoposlužne tehnologije od potrošača s manjom razinom obrazovanja. Kroz ovo istraživanje, autori su dobili podatke i o tome koje vrste inovacija na hrvatskom maloprodajnom tržištu potrošači prepoznaju, pa je tako $59 \%$ potrošača čulo za samoposlužne blagajne.

\section{Istraživanje (ne)prihvaćenosti samoposlužnih blagajni prilikom kupovine među potrošačima u Republici Hrvatskoj}

\subsection{Metodologija istraživanja}

S ciljem istraživanja (ne)prihvaćenosti samoposlužnih blagajni prilikom kupovine među mladim potrošačima u Republici Hrvatskoj provedeno je kvalitativno istraživanje i to metodom fokus grupe. Razlog da su istraživanjem obuhvaćeni samo mladi potrošači generacije $\mathrm{Y}$ je taj jer su oni rođeni i odgojeni u vrijeme 
digitalnog doba zbog čega su rani zagovarači inovativnih trendova (Rogers, 1962). Istraživanje je provedeno u svibnju 2016. godine u prostorijama Ekonomskog fakulteta Sveučilišta u Zagrebu, pod kontroliranim uvjetima.

Ciljevi ovog istraživanja su:

Ad 1) otkriti prihvaćenost samoposlužnih blagajni na hrvatskom maloprodajnom tržištu,

Ad 2) otkriti razloge korištenja odnosno (ne)korištenja samoposlužnih blagajni prilikom kupovine od strane mladih hrvatskih potrošača,

Ad 3) istražiti potrošačeva dosadašnja iskustva te mogućnost eventualnih promjena koje bi mogle biti napravljene kako bi potrošači češće koristili tu vrstu tehnologije.

Istraživanje je provedeno putem grupnog intervjua/diskusije, a instrumenti istraživanja bili su podsjetnici za intervju (Prilog 1 i Prilog 2). Pitanja postavljena ispitanicima fokus grupa su podijeljena u nekoliko kategorija, koje su se nametnule kao relevantne prilikom proučavanja literature: (1) osobnost i tehnološka spremnost korisnika i nekorisnika samoposlužne blagajne; (2) učestalost kupovine samoposlužnom blagajnom i način plaćanja; (3) sigurnost osobnih podataka; (4) tehničke pogreške; (5) percipirani utjecaj samoposlužnih blagajni na smanjenje prodajnog osoblja; (6) mogućnosti unaprjeđenja samoposlužne blagajne i (7) poznavanje $i$ korištenje ostalih samoposlužnih tehnologija u maloprodaji.

Znanstvena pozadina rada i kreiranih podsjetnika za intervju za obje fokus grupe su dosadašnja inozemna i domaća znanstvena istraživanja provedena na temu prihvaćenosti i primjene samoposlužnih tehnologija u maloprodaji (Curran i Meuter, 2005; Cunningham, Young i Gerlach, 2009; Chih-Hung Wang, 2012; Eastlick, Ratto, Lotz i Mishra, 2012; Lee i Yang, 2013; Hilton, Hughes, Little i Marandi, 2013; Åkesson i sur., 2014; Boon-itt, 2015; Kokkinou i Cranage, 2015).

U svrhu ostvarivanja ciljeva ovoga rada, ispitanici su bili podijeljeni u dvije fokus grupe. Prvu fokus grupu (FGl) činili su ispitanici koji prilikom svojih kupovina robe široke potrošnje učestalo koriste samoposlužnu blagajnu, a drugu fokus grupu (FG2) ispitanici koji ne koriste samoposlužnu blagajnu. U prvoj fokus bilo je devet ispitanika, drugoj šest, a svi ispitanici su bili mlađe životne dobi. Dodatan opis ispitanika koji koriste samoposlužne tehnologije, odnosno njihova sociodemografska obilježja vidljive su iz Tablice 1 . 
Tablica 1.

SOCIODEMOGRAFSKA OBILJEŽJA ISPITANIKA KOJI KORISTE SAMOPOSLUŽNU BLAGAJNU

\begin{tabular}{|c|l|l|l|l|l|}
\hline Ispitanik & Spol & \multicolumn{1}{|c|}{ Dob } & $\begin{array}{l}\text { Završen stupanj } \\
\text { obrazovanja }\end{array}$ & \multicolumn{1}{|c|}{ Zanimanje } & Radni status \\
\hline Ispitanik 1. & Ženski & 26. godina & $\begin{array}{l}\text { Prvostupnica } \\
\text { ekonomije }\end{array}$ & $\begin{array}{l}\text { Referentica u odjelu } \\
\text { za odnose s kupcima }\end{array}$ & Zaposlena \\
\hline Ispitanik 2. & Ženski & 24. godine & $\begin{array}{l}\text { Prvostupnica } \\
\text { ekonomije }\end{array}$ & Studentica & Nezaposlena \\
\hline Ispitanik 3. & Ženski & 24. godine & $\begin{array}{l}\text { Prvostupnica } \\
\text { ekonomije }\end{array}$ & Studentica & Zaposlena \\
\hline Ispitanik 4. & Ženski & 24. godine & $\begin{array}{l}\text { Prvostupnica } \\
\text { ekonomije }\end{array}$ & Studentica & Zaposlena \\
\hline Ispitanik 5. & Muški & 26. godina & SSS-gimnazija & $\begin{array}{l}\text { Stručni referent } \\
\text { otpreme pošte }\end{array}$ & Zaposlen \\
\hline Ispitanik 6. & Ženski & 26. godina & VSS & Magistra ekonomije & Zaposlena \\
\hline Ispitanik 7. & Muški & 26. godina & VSS & $\begin{array}{l}\text { Stručni specijalist } \\
\text { elektrotehnike }\end{array}$ & Zaposlen \\
\hline Ispitanik 8. & Ženski & 26. godina & SSS-gimnazija & Student & Nezaposlena \\
\hline Ispitanik 9. & Ženski & 26. godina & $\begin{array}{l}\text { Prvostupnica } \\
\text { ekonomije }\end{array}$ & Ekonomistica & Nezaposlena \\
\hline
\end{tabular}

Prvu fokus grupu činilo je devet ispitanika, od toga je sedam ispitanika ženskog spola, a dva muškog. Svi ispitanici su između 24. i 26. godine života. Što se tiče postignutog stupnja obrazovanja, dvoje ispitanika ima visoku stručnu spremu, njih petero ima prvostupničku diplomu, a preostalih dvoje srednju stručnu spremu odnosno završenu gimnaziju. Većina ispitanika, odnosno njih šestero, je u radnom odnosu, a troje ih je nezaposleno.

Drugu fokus grupu činilo je šest ispitanika, od toga pet ispitanika ženskog spola i samo jedan ispitanik muškog spola. Petero ispitanika je u 26. godini života, a jedan ispitanik ima navršenih 27 godina. Što se tiče stupnja obrazovanja, dvoje ispitanika ima završenu visoku stručnu spremu, jedan ispitanik ima završen specijalistički diplomski stručni studij, jedan ispitanik prvostupničku diplomu, a preostala dva ispitanika imaju završenu srednju stručnu spremu. Troje ispitanika je u radnom odnosu, a troje ih je nezaposleno. Demografska su obilježja ispitanika koji su sudjelovali u drugoj fokus grupi vidljiva iz Tablice 2. 
K. MATIĆ, K. PETLJAK, I. ŠTULEC: Prihvaćenost samoposlužnih blagajni prilikom kupovine robe široke potrošnje... EKONOMSKI PREGLED, 70 (2) 301-339 (2019)

Tablica 2.

\section{SOCIODEMOGRAFSKA OBILJAŽJA ISPITANIKA KOJI NE KORISTE SAMOPOSLUŽNU BLAGAJNU}

\begin{tabular}{|c|c|c|c|c|c|}
\hline Ispitanik & Spol & $D o b$ & $\begin{array}{c}\text { Završen stupanj } \\
\text { obrazovanja }\end{array}$ & Zanimanje & Radni status \\
\hline Ispitanik 1. & Ženski & 26. godina & SSS-gimnazija & Studentica & Zaposlena \\
\hline Ispitanik 2. & Ženski & 26. godine & $V S S$ & $\begin{array}{l}\text { Magistra } \\
\text { ekonomije }\end{array}$ & Nezaposlena \\
\hline Ispitanik 3. & Muški & 27. godine & $S S S$ & $\begin{array}{l}\text { Tehničar za } \\
\text { računalstvo }\end{array}$ & Zaposlen \\
\hline Ispitanik 4. & Ženski & 26. godine & $V S S$ & $\begin{array}{l}\text { Magistra } \\
\text { ekonomije }\end{array}$ & Nezaposlena \\
\hline Ispitanik 5. & Ženski & 26. godina & $\begin{array}{l}\text { Prvostupnica } \\
\text { novinarstva }\end{array}$ & Studentica & Nezaposlena \\
\hline Ispitanik 6. & Ženski & 26. godina & $\begin{array}{l}\text { Specijalistički } \\
\text { diplomski stručni } \\
\text { studij }\end{array}$ & \begin{tabular}{|l} 
Stručna \\
specijalistica \\
projektnog \\
menadžmenta
\end{tabular} & Zaposlena \\
\hline
\end{tabular}

\subsection{Rezultati istraživanja}

\subsubsection{Rezultati istraživanja provedenog među korisnicima samoposlužne tehnologije}

\subsubsection{Osobnost i tehnološka spremnost korisnika samoposlužne tehnologije}

Prvi, uvodni, blok pitanja čine pitanja vezana uz društvenost potrošača, njihove navike u kupovini te tehnološku spremnost. Svi ispitanici sebe percipiraju društvenim tipovima osobe te vole komunicirati s ljudima. Većina ispitanika kada kupuje robu široke potrošnje, vole kupovati sami zbog toga što u tom slučaju kupovinu obave brže, osim Ispitanika br. 4. koji uvijek kupuje u društvu. Ispitanici komuniciraju sa prodajnim osobljem kada neki od željenih proizvoda ne mogu pronaći, te ovisno o tome kakvog je raspoloženja prodajno osoblje. Ako je prodajno osoblje ljubazno ispitanici su slobodniji komunicirati s njima, no ispitanici 
smatraju da je prodajno osoblje u većini slučajeva neljubazno te pokušavaju potrošačima prodati nešto što ne trebaju.

Svi ispitanici vole koristiti tehnologiju te koriste tehnologiju u različite svrhe poput zabave, plaćanja računa, koriste se bankomatima i slično. Koriste tehnologiju gdje god mogu, ovisno o tome koliko im je ona dostupna i korisna, odnosno koliko ubrzava neki proces. Kada je riječ o samoposlužnoj tehnologiji, dio ispitanika smatra da im samoposlužna tehnologija olakšava život zbog toga što im samoposlužna tehnologija, poput samoposlužne blagajne ubrzava proces kupovine. Drugi dio ispitanika smatra da im ubrzava proces kupovine samo ako imaju manji broj artikala (te da bi trebalo postojati ograničenje, do koliko artikala se može koristiti samoposlužna blagajna) te ukoliko ne dođe do tehničke pogreške.

U nastavku su izdvojene izjave ispitanika koje se tiču osobnosti i tehnološke spremnosti korisnika samoposlužne tehnologije.

Ispitanik br. 3: „Smatram da bi samoposlužna tehnologija tj. samoposlužna blagajna olakšavala život kad bi ubrzala proces kupovine te kada bi se svi potrošači koji kupuju uz pomoć samoposlužne blagajne znali s njom koristiti što nije slučaj u Hrvatskoj. Proces je kupovine uz pomoć samoposlužne blagajne u Hrvatskoj sporiji u odnosu na druge zemlje..."

Ispitanik br. 7: „Samoposlužna tehnologija tj. samoposlužna blagajna olakšava mi život jer svoju kupovinu puno brže obavim, ne moram komunicirati s prodajnim osobljem, a osim toga volim i znam se koristiti tehnologijom..."

\subsubsection{Učestalost kupovine samoposlužnom blagajnom i način plaćanja}

Ispitanici često koriste samoposlužne blagajne, gotovo prilikom svake kupnje, no njihov izbor ovisi također i o dužini reda na tradicionalnoj blagajni, broju proizvoda koji kupuju (ukoliko imaju manji broj proizvoda kupuju uz pomoć samoposlužne blagajne), o tome gdje se samoposlužna blagajna nalazi (ukoliko je tradicionalna blagajna slobodna i bliža odlučuju se za nju). Okvirni iznos košarice kada kupuju uz pomoć samoposlužne blagajne je količinski do 10 artikala, odnosno vrijednosno do $200 \mathrm{kn}$.

U nastavku su izdvojene izjave ispitanika koje se tiču učestalosti kupovine samoposlužnom blagajnom i načinima plaćanja.

Ispitanik br. 7.: „Koristim samoposlužnu blagajnu prilikom svake kupovine čak i kada imam veći broj proizvoda u košarici..."

Ispitanicima nije bitno koju grupu proizvoda kupuju (prehrambene ili neprehrambene proizvode) kada koriste samoposlužnu blagajnu, iako je uglavnom 
riječ o prehrambenim proizvodima. Izbjegavaju kupovinu voća i povrća na samoposlužnoj blagajni jer se učestalo javljaju pogreške prilikom kupovine te vrste proizvoda samoposlužnom blagajnom.

Kada kupuju uz pomoć samoposlužne blagajne ispitanici uglavnom plaćaju karticom jer im je praktičnije i jednostavnije te znaju da na taj način neće imati problema s vraćanjem novaca, no Ispitanici br. 8. i 9. preferiraju gotovinsko plaćanje zbog straha od mogućnosti praćenja osobnih podataka i kupovina-dio potrošača smatra da je praćenje njihovih kupovina u redu jer dobivaju obavijesti za popuste proizvoda koje kupuju.

Prilikom prve kupovine uz pomoć samoposlužne blagajne dio ispitanika se osjećao neobično te nisu znali gdje trebaju ubaciti novce, ostalim ispitanicima je prvo iskustvo bilo zabavno i zanimljivo. Glavni razlog zbog kojeg se ispitanici odlučuju za kupovinu uz pomoć samoposlužne blagajne je zato što vole koristiti tehnologiju, a osim toga zbog želje da isprobaju nešto novo.

Ispitanici smatraju da su samoposlužne blagajne teško uočljive unutar prodavaonice zbog boje samoposlužnih blagajni, te da su zabačene na krajevima prodavaonice (iako su u nekim prodavaonicama u sredini što ispitanici smatraju puno uočljivijim).

Ispitanik br. 3.: „U svojoj sam prodavaonici tek nedavno primijetila samoposlužne blagajne iako ostali potrošači govore da su duže vrijeme tamo, upravo zbog tog razloga jer nisu postavljene na odgovarajući mjesto te nisu uočljive potrošačima..."

Ispitanik br. 2 preferira kupovati u prodavaonici koja ima mogućnost kupovine samoposlužnom blagajnom, drugi dio ispitanika smatra da je to nevažno.

\subsubsection{Stavovi korisnika o prednostima i nedostacima samoposlužne blagajne}

Kada je riječ o prednostima samoposlužnih blagajni ispitanici izdvajaju: (1) besplatne vrećice, (2) privatnost kupovine, (3) privatnost kod unošenja pina 4.2kartice, (4) nitko od ostalih potrošača koji čekaju red ne može doći dok se samoposlužna blagajna u potpunosti ne oslobodi, (5) brzinu ako je u košarici manji broj proizvoda i ako se ne pojavi tehnička pogreška i (6) činjenicu da uglavnom nema reda na samoposlužnim blagajnama. Kao koristi za prodavaonicu navode: smanjenje troškova zaposlenika ukoliko potrošači u potpunosti prihvate samoposlužne blagajne i da samoposlužne blagajne smanjuju gužvu u prodavaonici. 
Kao nedostatke samoposlužnih blagajni ispitanici navode: (1) vaga na samoposlužnoj blagajni ne registrira da je lagani proizvod (poput maramica) nakon skeniranja stavljen na vagu što uzrokuje nemogućnost očitavanja ostalih proizvoda iz košarice prije no prodajno osoblje ukloni tehničku pogrešku, (2) nemogućnost samoposlužne blagajne da vrati određeni iznos novca što također uzrokuje javljanje tehničke pogreške na samoposlužnoj blagajni i onemogućuje završetak kupovine (Ispitanik br. 6. je ubacio 500 kn u samoposlužnu blagajnu kako bi platio i završio kupovinu, međutim samoposlužna blagajna je taj isti iznos vratila te je ispitanik morao ići na tradicionalnu blagajnu razmijeniti novac kako bi završio kupovinu.), (3) ukoliko se uz pomoć samoposlužne blagajne kupuje alkohol ili cigarete (cigarete daje prodajno osoblje, potrošač nema mogućnost samostalno uzeti cigarete) prodajno osoblje mora potvrditi da je potrošač stariji od 18. godina te ukloniti zaštitu, zaštita se također mora ukloniti sa proizvoda većih vrijednosti (npr. kozmetika), (4) ukoliko potrošač nakon kupovine želi naljepnice čijim se skupljanjem mogu ostvariti dodatne pogodnosti i popusti mora čekati prodajno osoblje da mu naljepnice naknadno donese, (5) dio samoposlužnih blagajni radi samo za gotovinsko plaćanje, a dio samo za plaćanjem karticom, (6) otežana kupovina voća i povrća, tj. proizvoda za vaganje, samoposlužna blagajna u tom slučaju često zablokira, (7) nemogućnost prepoznavanja vrsta voća i povrća (može se zalijepiti bar kod od jeftinije vrste voća, povrća - blagajnik na tradicionalnoj blagajni to može primijetiti, a samoposlužna blagajna ne može), (8) olakšanu krađu proizvoda - ukoliko nema prodajnog osoblja u blizini potrošač može skenirati samo jedan od više istih artikala i završiti kupovinu, (9) potrošači imaju problem s pronalaskom bar koda, (10) ako je bar kod zgužvan, teže ga je očitati, (11) nemogućnost istovremenog skeniranja proizvoda i pakiranja u vrećicu - proizvod mora biti na vagi do završetka kupovine tj. nemogućnost da jedna osoba pakira proizvode, a druga skenira kao na tradicionalnoj blagajni i (12) prodajno osoblje nije uvijek na samoposlužnim blagajnama.

\subsubsection{Stavovi korisnika samoposlužne blagajne o sigurnosti osobnih podataka}

Ispitanici su upoznati sa pojmom krađe osobnih podataka te su svjesni tog problema i posljedica koji on može donijeti, no smatraju da kupovina uz pomoć samoposlužne blagajne ne donosi veći rizik krađe osobnih podataka od kupovine na tradicionalnoj blagajni. 


\subsubsection{Stavovi korisnika samoposlužne blagajne o tehničkim pogreškama}

Ispitanici navode kako gotovo prilikom svake kupovine uz pomoć samoposlužne blagajne uočavaju neke od njezinih nedostataka te se susreću sa tehničkim poteškoćama, zbog toga je izdvojeno još nekoliko događaja koji opisuju tehničke poteškoće samoposlužne blagajne te reakciju ispitanika koji se s njom susreo. Ispitanici također napominju da se i na tradicionalnim blagajnama javljaju greške te smatraju da to nije razlog da ne koriste samoposlužnu blagajnu. Svi ispitanici su nastavili s kupovinom uz pomoć samoposlužne blagajne usprkos čestim tehničkim poteškoćama.

U nastavku su izdvojene izjave ispitanika koje se odnose na stavove korisnika samoposlužne blagajne o tehničkim pogreškama.

Ispitanik br. 1: „Samoposlužna blagajna nije mogla očitati proizvod (bar kod nije bio prihvaćen), te nije mogao završiti kupovinu. Prodajnom osoblju je trebalo duže vrijeme da dođe ukloniti problem (jer se istovremeno pojavila greška na još dvije blagajne)... Osjećala sam se frustrirano te sam pomislila kako bi bilo bolje da sam obavila kupovinu na tradicionalnoj blagajni...Ipak sam i poslije tog događaja i dalje koristila samoposlužnu blagajnu..."

Ispitanik br. 7: „Kupovao sam proizvod koji je bio na akciji te sam očitao krivi bar kod, prodajno osoblje je primijetilo problem, poništilo očitani artikl te mi objasnilo da moram prekriti staru cijenu (bar kod) te ručnim skenerom očitati sniženu cijenu, prodajno osoblje je došlo samoinicijativno i brzo nakon uočene greške..."

Ispitanik br. 4.: „Kupovala sam božićne poklone (igračke), iznos kupovine bio je do 700 kn koji sam htio platiti Multiplus karticom na kojoj je bio traženi iznos, samoposlužna blagajna je zablokirala te prodajno osoblje nije znalo ukloniti problem (čak su dvije djelatnice pokušale ukloniti tehničku pogrešku). Čekala sam minimalno 10 minuta dok voditelj poslovnice nije uklonio problem..."

Ispitanik br. 5.: „Smatram da je samoposlužna blagajna kraće vrijeme u Republici Hrvatskoj te da će se s vremenom smanjiti broj pogrešaka i doći do njezina unaprjeđenja. Osim toga smatram da mora postojati vrijeme prilagodbe potrošača na takvu vrstu tehnologije..."

\subsubsection{Stavovi korisnika samoposlužne blagajne o njezinom utjecaju na smanjenje prodajnog osoblja}

Ispitanici smatraju da samoposlužne blagajne neće još neko vrijeme utjecati na smanjenje broja prodajnog osoblja, budući da samoposlužna blagajna nije još u 
potpunosti prihvaćena (od strane svih potrošača) te da je zbog tehničkih pogrešaka koje se učestalo pojavljuju još uvijek potreban ljudski faktor.

U nastavku su izdvojene izjave ispitanika koje se odnose na stavove korisnika samoposlužne blagajne o njezinom utjecaju na smanjenje prodajnog osoblja.

Ispitanik br. 4. čitajući članke u novinama dolazi do informacije da se broj prodajnog osoblja u maloprodavaonicama koje imaju mogućnost kupovine uz pomoć samoposlužne blagajne ne bi trebao smanjiti no da bi trebalo doći do preraspodjele zaposlenika sa tradicionalnih blagajni na radna mjesta poput slaganja polica, pomoć potrošačima i sl.

Ispitanik br. 1. konstatira da svaka implementacija tehnologije u proces ima za cilj smanjenje troškova, pa tako i troška ljudskog faktora-plaća i naknada.

Ispitanik br. 7. smatra da prodajno osoblje nije dovoljno obučeno za rad na samoposlužnim blagajnama te da se na samoposlužnim blagajnama treba zaposliti stručnije osoblje, npr. mlade ljude, studente i sl.

\subsubsection{Stavovi korisnika samoposlužne blagajne o njezinom mogućem unaprjeđenju}

Svi ispitanici smatraju da samoposlužna blagajna ima velik potencijal za napredak te da treba biti unaprijeđena. Ispitanici predlažu slijedeća unaprjeđenja: (1) veći prostor za kupovinu i pakiranje, (2) mogućnost skeniranja glomaznih proizvoda, (3) tehnički osposobljen kadar kao ispomoć na samoposlužnim blagajnama koji bi bio uvijek prisutan, (4) upute za kartično plaćanje (različite kartice se različito koriste, a uputa na samoposlužnoj blagajni nema), (5) ograničenje količine proizvoda kod kupovine na samoposlužnoj blagajni i (6) rješavanje problema sa vaganjem (voća, povrća).

\subsubsection{Stavovi korisnika samoposlužnih blagajna o ostalim samoposlužnim tehnologijama u maloprodaji}

Nitko od ispitanika nije kupovao robu široke potrošnje preko Interneta, smatraju da bi proizvodi koje bi dobili mogli biti lošije kvalitete (meso, voće, povrće), s rokom trajanja na izmaku i sl.

U nastavku su izdvojene izjave ispitanika koje se odnose na stavove korisnika samoposlužnih blagajna o ostalim samoposlužnim tehnologijama u maloprodaji. 
Ispitanik br. 3 navodi da dostavljač prilikom dostave robe široke potrošnje kupljene putem Interneta napominje da se roba pregleda prije preuzimanja.

Ispitanik br. 7 je isprobao kupovinu uz pomoć prijenosnog skenera (eng. selfscanning) te nije zadovoljan jer prodajno osoblje pregledava robu prije same naplate, proizvodi se vade iz košarice i tek nakon pregledavanja proizvodi se pakiraju u vrećicu. Smatra da se zbog toga gubi osjećaj privatnosti te preferira samoposlužпи blagajnu. Predlaže unaprjeđenje kupovine uz pomoć prijenosnog skenera na način da se postavi vaga na pod na koju bi potrošač zajedno s košaricom stavio sve proizvode. Težina košarice bi se odbila te bi imali ukupnu težinu samih proizvoda. Potrošači u tom slučaju ne bi morali svaki proizvod posebno skenirati i stavljati iz košarice na vagu, a maloprodavači bi bili osigurani od mogućih krađa.

Ispitanik br. 2. smatra da bi prijenosni skener bio pogodan za prodavaonice odjećom i obućom te prodavaonice namještaja.

Ispitanicima se sviđa koncept $m$-scanninga, radiofrekvencijskih čipova, u kojem nema potrebe za vađenjem proizvoda iz košarice nego se svi željeni proizvodi automatski skeniraju, te smatraju da takva vrsta tehnologije neće doći uskoro u Hrvatsku jer nema dovoljno obrazovanog kadra za implementaciju naprednih oblika tehnologija.

4.2.2. Rezultati istraživanja provedenog među ispitanicima koji ne koriste samoposlužne blagajne

\subsubsection{Osobnost i tehnološka spremnost nekorisnika samoposlužne blagajne}

Svi ispitanici se bolje osjećaju u društvu te se percipiraju društvenim tipovima osobe osim Ispitanika broj 3. koji za sebe smatra da nije društveni tip osobe te se bolje osjeća sam nego u društvu. Osim toga svi ispitanici svoju kupovinu vole obaviti nekada sami, a nekada u društvu, ovisno o vremenu koje imaju na raspolaganju za kupovinu, osim Ispitanika br.1. koji preferira kupovinu u društvu, kako bi imala pomoć prilikom odabira, pakiranja kupljenih proizvoda. Svi ispitanici komuniciraju s osobljem, kada ne mogu nešto pronaći ili kada cijena nije jasno istaknuta te kada ne mogu doći do željenog proizvoda. Smatraju da ljubaznost osoblja ovisi o situaciji i individualno od osobe do osobe, a osim toga smatraju da je u nekim prodavaonicama teško doći do osoblja.

U nastavku su izdvojene izjave ispitanika koje se odnose na osobnost i tehnološku spremnost nekorisnika samoposlužne blagajne. 
Ispitanik br. 6. primjećuje da je u maloprodajnom lancu Lidl broj zaposlenih smanjen te je jedan zaposlenik raspoređen za brigu o više redova, odnosno da je potrebno proći cijelu prodavaonicu da se dođe do prodajnog osoblja te da potrošač nakon što uoči prodajno osoblje više ga i ne treba jer je problem samostalno riješio.

Što se tiče primjene tehnologije, svi ispitanici koriste tehnologiju učestalo, uglavnom za komunikaciju, zabavu no i za plaćanje računa, posao (i-pad) te prate tehnološke inovacije. Svi ispitanici su barem jednom kupovali na samoposlužnoj blagajni, razlog zbog kojeg su se odlučili samostalno isprobati samoposlužnu blagajnu bila je znatiželja, želja da isprobaju nešto novo. Međutim ispitanici smatraju da to iskustvo nije bilo pozitivno i uspješno. U početku su mislili da će im samoposlužna blagajna olakšati život te da će im ubrzati proces kupovine no na kraju su shvatili da je samoposlužna blagajna sporija od tradicionalne jer blagajnik već zna gdje se nalaze bar kodovi, skenira brzo, dok blagajnik skenira artikle potrošač sprema proizvode u vrećicu i dr. Potrošač za razliku od blagajnika prilikom kupovine uz pomoć samoposlužne blagajne mora paziti da mu svaki artikl bude skeniran, teško nalazi bar kod za skeniranje te ima problem sa naplatom, samoposlužna blagajna ne prihvaća uvijek novčanicu, često javlja tehničku pogrešku što dovodi do usporavanja procesa kupovine te izaziva nervozu kod potrošača jer zna da netko iza njega čeka red.

\subsubsection{Stavovi nekorisnika o prednostima i nedostacima samoposlužne blagajne}

Kao nedostatke samoposlužne blagajne ispitanici koji ih ne koriste navode: (1) kupovina samoposlužnom blagajnom traje duže nego tradicionalnom blagajnom, (2) nedostatak osobnog kontakta, (3) komplikacije koje nastaju prilikom kupovine na samoposlužnoj blagajni, a potrošači ih ne mogu riješiti samostalno (mora biti barem jedna osoba zadužena za pomoć što samoposlužnu blagajnu više ne čini samoposlužnom), (4) otežanu kupovinu alkoholnih proizvoda te proizvoda veće vrijednosti koji imaju zaštitu koju prodajno osoblje mora ukloniti, (5) otežano ostvarivanje dodatnih poklona (npr. čaša) što također po mišljenju ispitanika usporava i komplicira cjelokupnu kupovinu, (6) zaposlenici na tradicionalnoj blagajni mogu dati dodatne informacije o akcijama i popustima dok samoposlužna blagajna ne može. Kao prednosti samoposlužnih blagajni za prodavaonicu ispitanici navode: (1) smanjenje troškova / ili bolju raspodjelu prodajnog osoblja, (2) bolju organizaciju polica, (3) prodajno osoblje bi imalo više vremena za pomoć potrošačima koji ne mogu pronaći određeni artikl, cijenu ili sl. Prednosti samoposlužnih 
K. MATIĆ, K. PETLJAK, I. ŠTULEC: Prihvaćenost samoposlužnih blagajni prilikom kupovine robe široke potrošnje...

EKONOMSKI PREGLED, 70 (2) 301-339 (2019)

blagajni za potrošače su: (1) ubrzanje procesa kupovine (iako ispitanici smatraju da to nije čest slučaj zbog tehničkih pogrešaka koje se učestalo javljaju), (2) za potrošače koji se ne percipiraju društvenim tipovima osobe mogućnost minimalne komunikacije tijekom kupovine.

\subsubsection{Stavovi nekorisnika samoposlužne blagajne o sigurnosti osobnih podataka}

Ispitanici nemaju strah od krađe osobnih podataka te smatraju da ne može doći do krađe osobnih podataka kupovinom na samoposlužnoj blagajni odnosno da jednaka mogućnost krađe osobnih podataka kao i na tradicionalnoj blagajni. Također smatraju da krađa proizvoda nije olakšana kupovinom na samoposlužnoj blagajni te je jednaka mogućnost krađe proizvoda kao i na tradicionalnoj blagajni.

\subsubsection{Stavovi nekorisnika samoposlužne blagajne o tehničkim pogreškama}

Ispitanici tvrde da se svaki put kada su kupovali uz pomoć samoposlužne blagajne pojavila neka vrsta problema. Ispitanik br. 1. govori da baš iz razloga što je sve to novo iz straha da ne pogriješi dogodi se greška, npr. nije znala provući karticu za bodove. Ispitanik br. 2. imao je problem s naplatom, vaganjem voća, Ispitanik br. 3. s naplatom alkoholnog pića (osoblje mora potvrditi da je kupac stariji od 18. godina).

Razlog zbog kojeg se odlučuju za tradicionalnu blagajnu umjesto samoposlužne je taj što očekuju da će se pojaviti neka vrsta problema prilikom naplate (prihvaćanje novčanica, kartica) i kupovine na samoposlužnoj blagajni te da će biti prisiljeni tražiti pomoć od osoblja što na kraju usporava proces kupovine. Osim toga većini ispitanika je ugodnije uspostaviti kontakt s blagajnikom. Samoposlužna blagajna im ne djeluje komplicirano no nemaju povjerenja u tehnologiju te se ne žele dovesti u situaciju da moraju čekati prodajno osoblje da im pomogne s naplatom na samoposlužnoj blagajni. Smatraju da se blagajnik bolje snalazi s naplatom proizvoda (npr. ako proizvod nema bar kod blagajnik taj problem riješi brže nego potrošač samostalno jer blagajnici imaju svoj šifranik, utipkaju bar kod ručno ili sl).

Ispitanik br. 6 govori da bi ти između ostalog osoblje trebalo biti izuzetno neljubazno da se odluči za kupovinu uz pomoć samoposlužne blagajne. 


\subsubsection{Stavovi nekorisnika samoposlužne blagajne o njezinom utjecaju na smanjenje prodajnog osoblja}

Većina ispitanika (osim Ispitanika br. 3) smatra da je prodajno osoblje dovoljno obučeno za pomoć na samoposlužnoj blagajni te problem riješe vrlo brzo. Također, svi ispitanici smatraju da bi broj prodajnog osoblja uz samposlužnu blagajnu trebao biti veći jer su bili u situaciji u kojoj je više potrošača istovremeno imalo tehničku pogrešku na samoposlužnoj blagajni. Smatraju da prodajno osoblje brzo ukloni problem te dolazi do potrošača u što krećem vremenskom roku.

Ispitanici smatraju da samoposlužne blagajne neće smanjiti broj zaposlenih jer je uvijek potreban ljudski faktor u prodavaonici te da se na samoposlužne blagajne još uvijek gleda kao na pomoćne blagajne te su one tamo samo kako bi se smanjio red na tradicionalnim blagajnama te za kupovinu manjeg broja artikala. Osim toga smatraju da se zaposlenici ne bi trebali otpustiti nego educirati za neki bolji posao i bolje raspodijeliti unutar prodavaonice kako bi se zadovoljile potrebe potrošača.

\subsubsection{Stavovi nekorisnika samoposlužne blagajne o njezinom mogućem unaprjeđenju}

Ispitanici smatraju da je javnost manje upoznata sa postojanjem samoposlužnih blagajni te načinom na koji se one koriste. Po mišljenju ispitanika pomoć od strane prodajnog osoblja potrošačima koji prvi put koriste samoposlužnu blagajnu bila bi puno efikasnija od bilo kakve grupne edukacije potrošača, npr. da prodajno osoblje pokaže potrošaču kako koristi samoposlužnu blagajnu prilikom prve kupovine (a ne da se potrošači samostalno upoznaju sa samoposlužnom blagajnom kao što je bio slučaj u Hrvatskoj). Ispitanici smatraju da bi u tom slučaju većina potrošača koristila samoposlužnu blagajnu što upućuje na pogrešku u uvođenju te tehnologije. Također više bi koristili samposlužnu blagajnu kada bi upute za korištenje samoposlužne blagajne bile jasnije te vizualno prikazane. Potrošači bi češće kupovali uz pomoć samoposlužne blagajne da njezinim korištenjem ostvaruju neke popuste ili dodatne bodove. Ispitanik br. 1. bi koristio samoposlužnu blagajnu kada bi kupovao manji broj artikala, dok ostali i dalje smatraju da je bolje otići na brzu tradicionalnu blagajnu. Ispitanici bi koristili samoposlužne blagajne kada bi sa sigurnošću znali da neće doći do tehničke pogreške. Ispitanici također smatraju da bi na samoposlužnim blagajnama trebao biti veći broj prodajnog osoblja jer su bili u situaciji u kojoj je više samoposlužnih blagajni imalo tehničkih problema te su morali duže vrijeme čekati kako bi prodajno osoblje došlo do njih i uklonilo problem. 
U nastavku su izdvojene izjave ispitanika koje se odnose na stavove nekorisnika samoposlužne blagajne o njezinom mogućem unaprjeđenju.

Ispitanik br. 6. smatra da bi turističke destinacije u Republici Hrvatskoj koje posjećuje velik broj turista/stanaca (priobalje) imalo više koristi od samoposlužnih blagajni jer su stranci naviknuti na primjenu te vrste tehnologije, ona bi im olakšala naplatu kupovine, stranci ne bi imali probleme s preračunom valute, te bi se na taj način mogli izbjeći nesporazumi u komunikaciji između potrošača (stranca) i prodajnog osoblja (npr. mogućnost izbora različitih stranih jezika na samoposlužnoj blagajni). Osim toga samoposlužne blagajne bi smanjile gužve u prodavaonicama tijekom sezone, a broj zaposlenih tijekom sezone se ne bi trebao povećati.

\subsubsection{Stavovi nekorisnika samoposlužnih blagajni o ostalim samoposlužnim tehnologijama u maloprodaji}

Ispitanici nisu upoznati sa pojmom prijenosni skener, te nisu zainteresirani za tu vrstu tehnologije, smatraju da ona također ne ubrzava proces kupovine te je također potreban ljudski faktor za provjeru skeniranih proizvoda. Ispitanici smatraju da je online kupovina robe široke potrošnje pogodna za starije osobe, trudnice i sl. no samo za određene proizvode (ne za voće i povrće), te su upoznati sa tom vrstom samoposlužne tehnologije. Ispitanici bi bili zainteresirani za tehnologiju koja uspoređuje cijene artikala te im nudi bolju/jeftiniju varijantu proizvoda te smatraju da bi jedino od takvih vrsta tehnologije uistinu imali koristi.

\subsection{Usporedba stavova korisnika i nekorisnika samoposlužne blagajne}

U Tablici 3. prikazani su stavovi korisnika i nekorisnika samoposlužne blagajne. Prikaz je radi lakše usporedbe podijeljen na osam različitih tema: osobnost i tehnološka spremnost ispitanika, učestalost kupovine samoposlužnom blagajnom i način plaćanja, prednosti i nedostatci samoposlužnih blagajni, sigurnost osobnih podataka, tehničke pogreške, utjecaj samoposlužnih blagajni na smanjenje prodajnog osoblja, unaprjeđenje samoposlužne blagajne te ostala samoposlužna tehnologija u maloprodaji. 


\section{Tablica 3 .}

\section{USPOREDBA STAVOVA KORISNIKA I NEKORISNIKA SAMOPOSLUŽNE BLAGAJNE}

\begin{tabular}{|c|c|c|}
\hline TEMA & $\begin{array}{c}\text { STAVOVI KORISNIKA SAMOPOSLUŽNE } \\
\text { BLAGAJNE }\end{array}$ & $\begin{array}{c}\text { STAVOVI NEKORISNIKA } \\
\text { SAMOPOSLUŽNE BLAGAJNE }\end{array}$ \\
\hline $\begin{array}{l}\text { Osobnost } i \\
\text { tehnološka } \\
\text { spremnost } \\
\text { korisnika i } \\
\text { nekorisnika } \\
\text { samoposlužne } \\
\text { blagajne }\end{array}$ & $\begin{array}{l}\text { o Društveni, vole komunicirati s ljudima. } \\
\text { o Vole kupovati sami. } \\
\text { o Prodajno osoblje je neljubazno. } \\
\text { o Vole koristiti tehnologiju. } \\
\text { o Samoposlužna blagajna ne ubrzava uvi- } \\
\text { jek proces kupovine. }\end{array}$ & $\begin{array}{l}\text { o Društveni, vole komunicirati s ljudima. } \\
\text { o Nekada vole kupovat sami, a nekada u } \\
\text { društvu. } \\
\text { o Ljubaznost osoblja ovisi od osobe do } \\
\text { osobe. } \\
\text { o Vole koristiti tehnologiju. } \\
\text { o Samoposlužna blagajna ne ubrzava pro- } \\
\text { ces kupovine. }\end{array}$ \\
\hline $\begin{array}{l}\text { Učestalost } \\
\text { kupovine } \\
\text { samoposlužnom } \\
\text { blagajnom } i \\
\text { način plaćanja }\end{array}$ & $\begin{array}{l}\text { o Gotovo prilikom svake kupovine, ovisno } \\
\text { o dužini reda na tradicionalnoj blagajni } \\
\text { i broju proizvoda koji žele kupiti (do } 10 \\
\text { proizvoda), do } 200 \mathrm{kn} \text {. } \\
\text { o Veći dio ispitanika preferira kartično } \\
\text { plaćanje zbog praktičnosti i jednostavno- } \\
\text { sti. } \\
\text { o Izbor prodavaonice ne ovisi o mogućno- } \\
\text { sti kupovine samoposlužnom blagajnom. }\end{array}$ & \\
\hline $\begin{array}{l}\text { Prednosti } i \\
\text { nedostatci } \\
\text { samoposlužnih } \\
\text { blagajni }\end{array}$ & $\begin{array}{l}\text { o Prednosti: besplatne vrećice, privatnost, } \\
\text { smanjenje gužve u prodavaonici, moguć- } \\
\text { nost smanjenja broja prodajnog osoblja, } \\
\text { ubrzavanje procesa kupovine ako se } \\
\text { kupuje manji broj proizvoda i ne pojavi } \\
\text { tehnička pogreška. } \\
\text { o Nedostatci: velik broj tehničkih pogre- } \\
\text { šaka, problemi s vaganjem proizvoda, } \\
\text { olakšana krađa, otežana kupovina al- } \\
\text { koholnih pića i cigareta te proizvoda } \\
\text { veće vrijednosti koji imaju zaštitu koju } \\
\text { prodajno osoblje mora ukloniti, oteža- } \\
\text { no ostvarivanje dodatnih poklona (npr. } \\
\text { čaša), problemi sa pronalaskom bar koda, } \\
\text { ako je bar kod zgužvan teže ga je očitati, } \\
\text { prodajno osoblje nije uvijek na samopo- } \\
\text { služnim blagajnama. }\end{array}$ & $\begin{array}{l}\text { o Prednosti: samoposlužna blagajna bi } \\
\text { trebala ubrzati proces kupovine, za po- } \\
\text { trošače koji nisu društveni tipovi osobe } \\
\text { mogućnost minimalne komunikacije ti- } \\
\text { jekom kupovine, smanjenje troškova ili } \\
\text { bolja raspodjela prodajnog osoblja, bolja } \\
\text { organizacija polica, prodajno osoblje bi } \\
\text { imalo više vremena za pomoć potrošači- } \\
\text { ma koji ne mogu pronaći određeni artikl, } \\
\text { cijenu ili sl. } \\
\text { o Nedostatci: učestale tehničke pogreške, } \\
\text { kupovina samoposlužnom blagajnom } \\
\text { traje duže nego tradicionalnom bla- } \\
\text { gajnom, nedostatak osobnog kontakta, } \\
\text { otežana kupovina alkoholnih pića te } \\
\text { proizvoda veće vrijednosti koji imaju za- } \\
\text { štitu koju prodajno osoblje mora ukloniti, } \\
\text { otežano ostvarivanje dodatnih poklona } \\
\text { (npr. čaša), blagajnik može dati dodatne } \\
\text { informacije o akcijama i popustima dok } \\
\text { samoposlužna blagajna ne može. }\end{array}$ \\
\hline
\end{tabular}


K. MATIĆ, K. PETLJAK, I. ŠTULEC: Prihvaćenost samoposlužnih blagajni prilikom kupovine robe široke potrošnje... EKONOMSKI PREGLED, 70 (2) 301-339 (2019)

\begin{tabular}{|c|c|c|}
\hline TEMA & $\begin{array}{c}\text { STAVOVI KORISNIKA SAMOPOSLUŽNE } \\
\text { BLAGAJNE }\end{array}$ & $\begin{array}{c}\text { STAVOVI NEKORISNIKA } \\
\text { SAMOPOSLUŽNE BLAGAJNE }\end{array}$ \\
\hline $\begin{array}{l}\text { Sigurnost } \\
\text { osobnih } \\
\text { podataka }\end{array}$ & $\begin{array}{l}\text { o Kupovina uz pomoć samoposlužne bla- } \\
\text { gajne ne donosi veći rizik krađe osobnih } \\
\text { podataka od kupovine na tradicionalnoj } \\
\text { blagajni. } \\
\text { o Olakšana mogućnost krađe proizvoda. }\end{array}$ & $\begin{array}{l}\text { o Nemaju strah od krađe osobnih podata- } \\
\text { ka, jednaka mogućnost krađe osobnih } \\
\text { podataka kao i na tradicionalnoj blagaj- } \\
\text { ni. } \\
\text { o Jednaka mogućnost krađe proizvoda kao } \\
\text { i na tradicionalnoj blagajni. }\end{array}$ \\
\hline $\begin{array}{l}\text { Tehničke } \\
\text { pogreške }\end{array}$ & $\begin{array}{l}\text { o Tehničke pogreške su učestale, ali to nije } \\
\text { razlog ne korištenja samoposlužne bla- } \\
\text { gajne. }\end{array}$ & $\begin{array}{l}\text { o Tehničke pogreške su učestale } \mathrm{i} \text { to je } \\
\text { glavni razlog ne korištenja samoposlužne } \\
\text { blagajne. }\end{array}$ \\
\hline $\begin{array}{l}\text { Utjecaj } \\
\text { samoposlužnih } \\
\text { blagajni na } \\
\text { smanjenje } \\
\text { prodajnog } \\
\text { osoblja }\end{array}$ & \begin{tabular}{|l} 
o Zbog velikog broja tehničkih pogrešaka \\
još je uvijek potreban ljudski faktor te u \\
kraćem roku neće doći do smanjena pro- \\
dajnog osoblja. \\
o $\begin{array}{l}\text { Dio ispitanika smatra da je potrebna edu- } \\
\text { kacija zaposlenika i stručniji kadar. }\end{array}$ \\
\end{tabular} & \begin{tabular}{|l} 
o Na samoposlužne blagajne se gleda kao \\
na pomoćne blagajne te neće doći do \\
smanjenja broja prodajnog osoblja. \\
o Samo jedan ispitanik smatra da prodajno \\
osoblje nije dovoljno obučeno za rad na \\
samposlužnim blagajnama.
\end{tabular} \\
\hline $\begin{array}{l}\text { Unaprjeđenje } \\
\text { samoposlužne } \\
\text { blagajne }\end{array}$ & 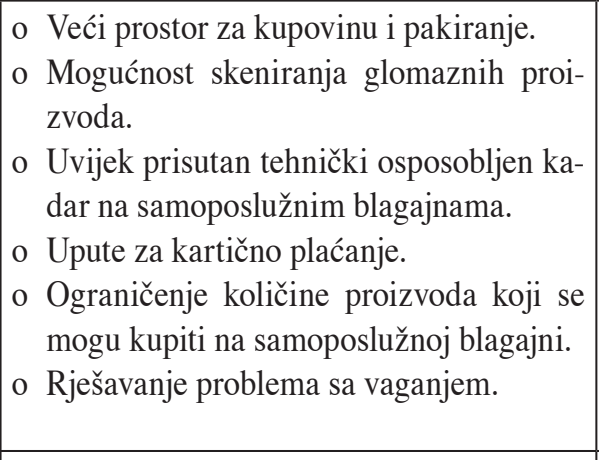 & $\begin{array}{l}\text { o Veći broj prodajnog osoblja na samopo- } \\
\text { služnoj blagajni. } \\
\text { o Pomoć prodajnog osoblja kod kupovine } \\
\text { prvi put. } \\
\text { o Jasnije upute za korištenje. } \\
\text { o Dodatni popustu za kupovinu na samo- } \\
\text { poslužnoj blagajni. } \\
\text { o Mogućnost kupovine samoposlužnom } \\
\text { blagajnom na turističkim mjestima u } \\
\text { Hrvatskoj. }\end{array}$ \\
\hline $\begin{array}{l}\text { Ostala } \\
\text { samoposlužna } \\
\text { tehnologija u } \\
\text { maloprodaji }\end{array}$ & $\begin{array}{l}\text { o Ne koriste drugu samoposlužnu tehnolo- } \\
\text { giju u maloprodaji. } \\
\text { o Zainteresirani za tehnologiju s kojom } \\
\text { nema potrebe za vađenjem proizvoda iz } \\
\text { košarice nego se svi željeni proizvodi au- } \\
\text { tomatski skeniraju. }\end{array}$ & $\begin{array}{l}\text { o Nemaju potrebu za isprobavanjem osta- } \\
\text { lih samoposlužnih tehnologija u malo- } \\
\text { prodaji. } \\
\text { o Ispitanici bi bili zainteresirani za teh- } \\
\text { nologiju koja uspoređuje cijene artikala } \\
\text { te im nudi cjenovno povoljniju varijantu } \\
\text { proizvoda. }\end{array}$ \\
\hline
\end{tabular}

Sljedeća Tablica 4. prikazuje usporedbu rezultata provedenog istraživanja s rezultatima prijašnjih istraživanja. I u ovom je slučaju prikaz radi lakše usporedbe podijeljen na osam različitih tema: (1) osobnost i tehnološka spremnost ispitanika, (2) učestalost kupovine samoposlužnom blagajnom i način plaćanja, (3) prednosti i nedostatci samoposlužnih blagajni, (4) sigurnost osobnih podataka, (5) tehničke pogreške, (6) utjecaj samoposlužnih blagajni na smanjenje prodajnog osoblja, (7) unaprjeđenje samoposlužne blagajne te (8) ostala samoposlužna tehnologija u maloprodaji. 


\section{Tablica 4.}

\section{USPOREDBA REZULTATA PROVEDENOG ISTRAŽIVANJA SA REZULTATIMA PRIJAŠNJIH ISTRAŽIVANJA}

\begin{tabular}{|c|c|c|}
\hline TEMA & PRIJAŠNJA ISTRAŽIVANJA & PROVEDENO ISTRAŽIVANJE \\
\hline $\begin{array}{l}\text { Osobnost i } \\
\text { tehnološka } \\
\text { spremnost } \\
\text { korisnika i } \\
\text { nekorisnika } \\
\text { samoposlužne } \\
\text { blagajne }\end{array}$ & $\begin{array}{l}\text { 1. Osobine potrošača određene su demografskim fak- } \\
\text { torima te predstavljaju varijable u izračunu namjere } \\
\text { potrošača hoće li ili neće koristiti samoposlužne } \\
\text { blagajne pa tako npr. stariji potrošači imaju veću } \\
\text { potrebu za komunikacijom sa prodajnim osobljem } \\
\text { nego mlađi potrošači (Lee, Cho, Xu i Fairhurst, } \\
\text { 2010). } \\
\text { 2. Tehnička spremnost ima jako mali utjecaj na odluku } \\
\text { potrošača hoće li ili neće koristiti samoposlužne } \\
\text { tehnologije (Elliott i sur., 2013). } \\
\text { 3. Potrebe potrošača za komunikacijom te nelago- } \\
\text { da (strah) od korišstenja tehnologije imaju snažan } \\
\text { utjecaj na odluku potrošača hoće li potrošač po- } \\
\text { stati potrošač samoposlužne tehnologije ili neće } \\
\text { (Kokkinou i Cranage, 2015). }\end{array}$ & $\begin{array}{l}\text { 1. Nije u skladu s prijašnjim istraživa- } \\
\text { njem. Ispitanici koji ne koriste samopo- } \\
\text { služnu blagajnu, iako su mlađe životne } \\
\text { dobi, imaju veću tendenciju prema } \\
\text { komuniciranju sa prodajnim osobljem } \\
\text { nego korisnici samoposlužne blagajne. } \\
\text { 2. U skladu sa prijašnjim istraživanjem, } \\
\text { obje grupe vole koristiti i koriste tehno- } \\
\text { logiju što upućuje na to da tehnološka } \\
\text { spremnost ima jako mali utjecaj na od- } \\
\text { luku potrošača hoće li ili neće koristiti } \\
\text { samoposlužne tehnologije. } \\
\text { 3. U skladu s prijašnjim istraživanje. } \\
\text { Ispitanici grupe koja ne koristi samo- } \\
\text { poslužnu blagajnu imaju potrebu za } \\
\text { komunikacijom s prodajnim osobljem } \\
\text { te nepovjerenje u tehnologiju-javljanje } \\
\text { tehničkih pogrešaka. }\end{array}$ \\
\hline $\begin{array}{l}\text { Učestalost } \\
\text { kupovine } \\
\text { samoposlužnom } \\
\text { blagajnom i } \\
\text { način plaćanja }\end{array}$ & $\begin{array}{l}\text { 1. Potrošači najčešće samoposlužne blagajne koriste } \\
\text { kad su žurbi, kad su redovi na tradicionalnim bla- } \\
\text { gajnama predugi te kada kupuju malo proizvoda } \\
\text { (najčešće manje od } 15 \text { proizvoda) (NCR, 2014). } \\
\text { 2. U prosjeku 70,54\% osoba odabire samoposlužnu } \\
\text { tehnologiju kad je red na blagajni s prodajnim oso- } \\
\text { bljem duži (Kokkinou i Cranage, 2015). } \\
\end{array}$ & $\begin{array}{l}U \text { skladu s prijašnjim istrǎ̌ivanjima. } \\
\text { Namjera ispitanika da koristi samoposluž- } \\
\text { nu blagajnu uglavnom ovisi o dužini reda } \\
\text { na tradicionalnoj blagajni i broju proizvoda } \\
\text { koji žele kupiti (do } 10 \text { proizvoda). } \\
\end{array}$ \\
\hline $\begin{array}{l}\text { Prednosti i } \\
\text { nedostatci } \\
\text { samoposlužnih } \\
\text { blagajni }\end{array}$ & $\begin{array}{l}\text { 1. Potrošačima se najviše sviđa praktičnost i jedno- } \\
\text { stavnost samoposlužnih blagajni. Većina potrošača } \\
\text { se složila s tvrdnjom da maloprodajne prodavaoni- } \\
\text { ce koje imaju samoposlužne blagajne pružaju bolju } \\
\text { korisničku podršku, a kao glavni razlog ne korišste- } \\
\text { nja samoposlužnih blagajni izdvajaju da preferiraju } \\
\text { pomoć zaposlenika na blagajnama za dodatna pita- } \\
\text { nja (NCR, 2014). } \\
\text { 2. Prilikom korištenja samoposlužne blagajne, potro- } \\
\text { šač shvaća da ona nije komplicirana za korištenje, } \\
\text { raste povjerenje prema prodavaonici u kojoj ima } \\
\text { mogućnost kupovine samoposlužnom blagajnom } \\
\text { te pruža osjećaj kontrole kupovine (Åkesson i sur., } \\
\text { 2014). }\end{array}$ & $\begin{array}{l}\text { Djelomično u skladu s prijašnjim istra- } \\
\text { živanjima. Ispitanici koji ne koriste samo- } \\
\text { poslužnu blagajnu preferiraju pomoć od } \\
\text { blagajnika koji ih obavještava o dodatnim } \\
\text { akcijama i pogodnostima, smatraju da sa- } \\
\text { moposlužna blagajna nije komplicirana za } \\
\text { upotrebu no nemaju povjerenja u tehnologi- } \\
\text { ju. Obje grupe ispitanika navode čitav niz } \\
\text { prednosti i nedostataka samoposlužne bla- } \\
\text { gajne koji se međusobno podudaraju. }\end{array}$ \\
\hline
\end{tabular}




\begin{tabular}{|c|c|c|}
\hline TEMA & PRIJAŠNJA ISTRAŽIVANJA & PROVEDENO ISTRAŽIVANJE \\
\hline $\begin{array}{l}\text { Sigurnost } \\
\text { osobnih } \\
\text { podataka }\end{array}$ & $\begin{array}{l}\text { 1. Kao glavni razlozi straha od korištenja tehnologije, } \\
\text { potrošači su naveli ugroženost privatnosti (vlastitih } \\
\text { privatnih podataka) i manjak sigurnosti, tj. moguć- } \\
\text { nost novčanog gubitka u slučaju npr. krađe podata- } \\
\text { ka s kreditnih kartica (Kovač i Bajkovec, 2015). }\end{array}$ & $\begin{array}{l}\text { Nije u skladu sa prijašnjim istraživanjem, } \\
\text { ispitanici obje grupe nemaju strah od mo- } \\
\text { gućnosti krađe osobnih podataka, odnosno } \\
\text { smatraju da je jednaka mogućnost krađe } \\
\text { podataka i na tradicionalnoj i na samopo- } \\
\text { služnoj blagajni. }\end{array}$ \\
\hline $\begin{array}{l}\text { Tehničke } \\
\text { pogreške }\end{array}$ & $\begin{array}{l}\text { 1. Na negativno mišljenje, odnosno nezadovoljstvo } \\
\text { potrošača samoposlužnom tehnologijom su najviše } \\
\text { utjecale tehničke pogreške kod samoposlužnih ure- } \\
\text { đaja. Na veće zadovoljstvo potrošača utječe i okoli- } \\
\text { na, što je okolina bila manje stresna to je zadovolj- } \\
\text { stvo potrošača prilikom korištenja samoposlužne } \\
\text { tehnologije bilo veće (Dabholkar i Spaid, 2012). }\end{array}$ & $\begin{array}{l}\text { U skladu sa prijašnjim istraživanjem. Ne } \\
\text { korisnici samoposlužne blagajne kao glavi } \\
\text { razlog nekorištenja samoposlužne blagajne } \\
\text { navode tehničke pogreške. Korisnici samo- } \\
\text { poslužne blagajne negativno gledaju na teh- } \\
\text { ničke pogreške no bez obzira na to koriste } \\
\text { samoposlužne blagajne. }\end{array}$ \\
\hline $\begin{array}{l}\text { Utjecaj } \\
\text { samoposlužnih } \\
\text { blagajni na } \\
\text { smanjenje } \\
\text { prodajnog } \\
\text { osoblja }\end{array}$ & $\begin{array}{l}\text { 1. Potrošači su gledali pozitivno na prodajno osoblje } \\
\text { koje bi im pomoglo prilikom kvarova ili problema } \\
\text { sa samoposlužnom tehnologijom, ali je to poveća- } \\
\text { lo nezadovoljstvo potrošača prema samoposlužnoj } \\
\text { tehnologiji (Dabholkar i Spaid, 2012). }\end{array}$ & $\begin{array}{l}\text { Djelomično u skladu s prijašnjim istraži- } \\
\text { vanjem. Grupa koja ne koristi samoposluž- } \\
\text { nu blagajnu gleda pozitivno na zaposlenike } \\
\text { koji su im pomagali prilikom kvarova ili } \\
\text { problema sa samoposlužnom tehnologijom, } \\
\text { a dio grupe koja koristi samoposlužnu bla- } \\
\text { gajnu smatra da zaposlenici nisu dovoljno } \\
\text { obučeni za rješavanje tehničkih problema. }\end{array}$ \\
\hline $\begin{array}{l}\text { Unaprjeđenje } \\
\text { samoposlužne } \\
\text { blagajne }\end{array}$ & $\begin{array}{l}\text { 1. Najviše potrošača je predložilo povećanje prosto- } \\
\text { ra za pakiranje proizvoda (45\%), te smatraju da bi } \\
\text { prodajno osoblje uvijek trebalo biti na raspolaganju } \\
\text { za pomoć pri kupovini na samoposlužnoj blagajni } \\
\text { (NCR, 2014). } \\
\text { 2. Samoposlužne blagajne mogu dodatno poslužiti kao } \\
\text { sredstvo ublažavanja sezonalnosti tj. opterećenja } \\
\text { sustava naplate u prodavaonicama u turističkim } \\
\text { područjima. Obzirom da samoposlužne blagajne } \\
\text { omogućavaju veću protočnost unutar prodavaonice } \\
\text { ublažavaju razlike u potrebi za radnom snagom za } \\
\text { vrijeme i izvan turističke sezone, a s obzirom na } \\
\text { višejezičnost stranim potrošǎcima pojednostavljuju } \\
\text { kupovinu (Guszaki sur., 2011). }\end{array}$ & $\begin{array}{l}\text { 1. U skladu s prijašnjim istraživanjem. } \\
\text { Obje grupe smatraju da bi prodajno oso- } \\
\text { blje uvijek trebalo biti na raspolaganju } \\
\text { za pomoć pri kupovini samoposlužnom } \\
\text { blagajnom. Korisnici samoposlužne } \\
\text { blagajne predlažu povećanje prostora za } \\
\text { kupovinu i pakiranje. } \\
\text { 2. U skladu s prijašnjim istraživanjem. } \\
\text { Ispitanik br. 6- nekorisnik samoposluž- } \\
\text { ne blagajne predlaže implementaciju } \\
\text { samoposlužnih blagajni u turističkim } \\
\text { gradovima Republike Hrvatske zbog } \\
\text { istih razloga. }\end{array}$ \\
\hline $\begin{array}{l}\text { Ostala } \\
\text { samoposlužna } \\
\text { tehnologija u } \\
\text { maloprodaji }\end{array}$ & $\begin{array}{l}\text { 1. Svi ispitanici koji su sudjelovali u istraživanju su } \\
\text { morali koristiti barem dvije vrste samoposlužne } \\
\text { tehnologije u zadnjih šest mjeseci. U istraživanju su } \\
\text { se autori orijentirali na četiri vrste samoposlužnih } \\
\text { tehnologija: 1. Internet alat i online vodič za izradu } \\
\text { kuhinje prije dolaska u prodavaonicu, 2. aplikaciju } \\
\text { za izradu liste za kupovinu, 3. brzu samoposlužnu } \\
\text { blagajnu, 4. aplikaciju za pregled dostupnosti proi- } \\
\text { zvoda u prodavaonici (Åkesson i sur., 2014). }\end{array}$ & $\begin{array}{l}\text { Nije u skladu s prijašnjim istraživanjem. } \\
\text { Svi ispitanici od samoposlužnih tehnologija } \\
\text { koristili su samo samoposlužnu blagajnu, } \\
\text { no postoji zainteresiranost za ostale samo- } \\
\text { poslužne tehnologije. Nekorisnici samopo- } \\
\text { služne blagajne bi bili zainteresirani za teh- } \\
\text { nologiju koja uspoređuje cijene artikala te } \\
\text { im nudi bolju/jeftiniju varijantu proizvoda, } \\
\text { a korisnici samoposlužne blagajne za tehno- } \\
\text { logiju koja automatski skenira sve proizvod } \\
\text { bez vađenja proizvoda iz košarice. }\end{array}$ \\
\hline
\end{tabular}




\subsection{Ograničenja istraživanja i preporuke za buduća istraživanja}

Kako bi se ostvarili ciljevi istraživanja, istraživanje je provedeno metodom fokus grupe, te su svi dobiveni podatci kvalitativne prirode. Kao glavno ograničenje provedenog istraživanja navodi se da su rezultati kvalitativne prirode. S ciljem potpunijeg razumijevanja i ostvarivanja istraživačkih ciljeva, predlaže se u budućnosti provođenje kvantitativnog istraživanja u samim prodavaonicama koje imaju samoposlužne blagajne. Metodom fokus grupe u potpunosti su ostvarenI ciljevi istraživanja te je za to primijenjena metoda idealna jer omogućuje prikupljanje velikog broja podataka vezanih uz stavove ispitanika. Većina ispitanika u obje fokus grupe smatra da samoposlužna blagajna kao tehnologija u hrvatskoj maloprodaji nije u potpunosti prihvaćena. Podjela ispitanika u dvije fokus grupe (korisnike i nekorisnike samoposlužnih blagajni), zbog kasnije usporedbe dobivenih podataka, je uvelike doprinijela potpunom ostvarenju zadnja dva cilja te da je ispitana samo jedna strana potrošača, cilj ne bi bio ostvaren, a podatci ne bi bili relevantni.

Metoda fokus grupe predstavlja vremenski zahtjevnu metodu prikupljanja podataka, što zbog potrebnog velikog napora moderatora da ostvari sinergiju grupe, a što zbog teškog određivanja idealnog broja ispitanika unutar grupe kao i transkribiranja i analize rezultata kvalitativnog intervjua. S obzirom na činjenicu da je u Hrvatskoj prihvaćenost samoposlužnih blagajni još uvijek neistraženo područje te da je ovo tek početak primjene suvremene tehnologije u hrvatskoj maloprodaji, ovo istraživanje predstavlja dobru eksplorativnu podlogu za sva buduća istraživanja u području samoposlužne tehnologije.

\section{Zaključak}

Ekonomska kriza i intenzivna konkurencija, koja je prisutna na današnjem maloprodajnom tržištu, maloprodavaču predstavlja sve složeniji i zahtjevniji zadatak privlačenja kupaca. Upravo se iz tog razloga maloprodavači nerijetko odlučuju za uvođenje tehnoloških inovacija s ciljem unapređenja poslovnih procesa, stvaranja prednosti u odnosu na konkurente te pružanja dodatnih usluga kupcima. Primjer takvih tehnoloških inovacija su samoposlužne tehnologije. Samoposlužna tehnologija nije zaobišla ni sektor maloprodaje pa je u tom kontekstu definirana kao tehnološko rješenje koje omogućava kupcima korištenje usluga bez podrške i pomoći prodajnog osoblja.

Budući da su potrošači danas spremni sve manje vremena provesti u kupovini, a za kratko vrijeme procesa kupnje zahtijevaju sve više informacija o proizvodima 
koje kupuju, glavni motivi za uvođenje samoposlužne tehnologije u prodavaonice su pružiti kupcima veći izbor usluga te omogućiti jednostavniju i bržu kupovinu. Najrasprostranjeniji primjeri primjene samoposlužnih tehnologija u maloprodaji izvan prodavaonica su prodajni automati, te Internet prodavaonice, kojima je moguće pristupiti putem osobnog računala i mobilnog telefona, a unutar prodavaonica najrasprostranjeniji oblici samoposlužne tehnologije su samoposlužne blagajne i prijenosni skeneri. Osim navedenih postoji još velik broj oblika samoposlužnih tehnologija unutar prodavaonice koje su manje razvijene na hrvatskom tržištu ili ih uopće nema, poput transakcijskih kioska, inteligentnih vaga, PSA uređaja, RFID tehnologije i drugih. Popularnost samoposlužne tehnologije u maloprodaji raste zbog čitavog niza prednosti koje donosi za potrošače, poduzeća te za gospodarstvo u cijelosti. Mogućnost primjene samoposlužne tehnologije na hrvatskom tržištu je vrlo oskudna.

U svrhu otkrivanja (ne)prihvaćenosti samoposlužnih blagajni od strane hrvatskih potrošača, razloga korištenja odnosno ne korištenja samoposlužnih blagajni od strane potrošača te prikupljanja ideja za moguća unaprjeđenja provedeno je istraživanje metodom fokus grupe. Sukladno tome, analizirajući rezultate istraživanja dolazi se do zaključka da samoposlužna blagajna još uvijek nije u potpunosti prihvaćena od strane mladih hrvatskih potrošača te da se na nju gleda isključivo kao na pomoćnu blagajnu. Ispitanici smatraju da je samoposlužna blagajna namijenjena za kupovinu manjeg broja artikala te je postavljenja u svrhu smanjenja reda na tradicionalnoj blagajni. Prilikom kupovine uz pomoć samoposlužne blagajne tehničke pogreške su učestale te je navedeno glavni razlog ne korištenja samoposlužne blagajne. Upravo zbog velikog broja tehničkih pogrešaka i dalje je potrebna prisutnost ljudskog faktora te ispitanici smatraju da neće doći do smanjenja prodajnog osoblja unutra prodavaonice. Što se tiče mogućih unaprjeđenja ispitanici predlažu veći prostor za kupovinu i pakiranje, mogućnost skeniranja glomaznih proizvoda, uvijek prisutan tehnički osposobljen kadar na samoposlužnim blagajnama, rješavanje problema s kupovinom i vaganjem voća i povrća, pomoć prodajnog osoblja kod kupovine prvi put, mogućnost kupovine samoposlužnom blagajnom na turističkim mjestima u Hrvatskoj i druge inovacije.

\section{Literatura:}

Åkesson, M., Edvardsson, B. i Tronvoll, B. (2014). Customer experience from a self-service system perspective. Journal of Service Management, (25)5, 677698. https://www.emeraldinsight.com/doi/full/10.1108/JOSM-01-2013-0016 https://doi.org/10.1108/JOSM-01-2013-0016 
Boon-itt, S. (2015). Managing self-service technology service quality to enhance esatisfaction. International Journal of Quality and Service Sciences, (7)4, 373 391. https://www.emeraldinsight.com/doi/full/10.1108/IJQSS-01-2015-0013 https://doi.org/10.1108/IJQSS-01-2015-0013

Chih-Hung Wang, M. (2012). Determinants and consequences of consumer satisfaction with self-service technology in a retail setting. Managing Service Quality: An International Journal, (22)2, 128-144. https://www.emeraldinsight.com/doi/full/10.1108/09604521211218945 https://doi.org/10.1108/09604521211218945

Cunningham, L. F., Young, C. E. i Gerlach, J. (2009). A comparison of consumer views of traditional services and self-service technologies. Journal of Services Marketing, (23)1, 11-23. https:/www.emeraldinsight.com/doi/ abs/10.1108/08876040910933057 https://doi.org/10.1108/08876040910933057

Curran, J. M. i Meuter, M. L. (2005). Self-service technology adoption: comparing three technologies. Journal of Services Marketing, (19)2, 103-113. https:// www.emeraldinsight.com/doi/full/10.1108/08876040510591411 https://doi.org/10.1108/08876040510591411

Dabholkar, P.A. i Spaid B.I. (2012). Service failure and recovery in using technology-based self-service: effects on user attributions and satisfaction. The Service Industries Journal, (32)9, 1415-1432. https://www.tandfonline.com/ doi/abs/10.1080/02642069.2011.600518 https://doi.org/10.1080/02642069.2011.600518

Dunković, D. i Brozović, I. (2011). Tehnološke inovacije u trgovini: Što očekivati i kako se pripremiti. U N. Knego, S. Renko i B. Knežević (Ur.), Trgovina kao pokretač razvoja Srednje i Jugoistočne Europe (str. 271-294). Zagreb, Ekonomski fakultet Sveučilišta u Zagrebu.

Dunković, D., Ružić, D. i Jurić, Đ. (2010). Informacijska tehnologija u funkciji napretka trgovine u recesiji, U S. Renko, B. Knežević i R. Vouk (Ur.), Izazovi trgovine u recesiji (str. 173-194). Zagreb, Ekonomski fakultet Sveučilišta u Zagrebu.

Eastlick, M. A., Ratto, C., Lotz, S. L. i Mishra, A. (2012). Exploring antecedents of attitude toward co-producing a retail checkout service utilizing a selfservice technology. The International Review of Retail, Distribution and Consumer Research, (22)4, 337-364. https://www.tandfonline.com/doi/abs/10.1080/095 93969.2012.690775 https://doi.org/10.1080/09593969.2012.690775

Elliott, M., Meng, G. i Hall, M. (2013). Consumers' intention to use self-scanning technology: the role of technology readiness and perceptions toward selfservice technology. Academy of Marketing Studies Journal, (17)1, 129- 
K. MATIĆ, K. PETLJAK, I. ŠTULEC: Prihvaćenost samoposlužnih blagajni prilikom kupovine robe široke potrošnje... EKONOMSKI PREGLED, 70 (2) 301-339 (2019)

143. Dostupno na https://www.abacademies.org/articles/amsjvol17no12013. pdf\#page $=137$

Guszak, I., Brčić-Stipčević, V. i Vouk, R. (2011). Samoposlužna tehnologija i tržišno pozicioniranje u maloprodaji proizvoda svakodnevne potrošnje, U N. Knego, S. Renko i B. Knežević (Ur.), Trgovina kao pokretač razvoja Srednje i Jugoistočne Europe (str. 295-307). Zagreb, Ekonomski fakultet Sveučilišta u Zagrebu.

Hilton, T., Hughes, T., Little, E. i Marandi, E. (2013). Adopting self-service technology to do more with less. Journal of Services Marketing, (27)1, 3-12. https:// www.emeraldinsight.com/doi/full/10.1108/08876041311296338 https://doi.org/10.1108/08876041311296338

Jatgovac (2011). Inovacije u maloprodaji: I pobjednik je... [online]. Zagreb: Jatrgovac. Dostupno na: http://www.jatrgovac.com/2011/05/inovacije-u-maloprodaji-i-pobjednik-je\%E2\%80\%A6/ (05.05.2018.)

Jatrgovac (2016). Konzum uveo više od 100 pametnih blagajni [online]. Zagreb: Jatrgovac. Dostupno na: http://www.jatrgovac.com/2016/03/konzum-uveovise-od-100-pametnih-blagajni/ (18.06.2018.)

Kokkinou, A. i Cranage, D. A. (2015). Why wait? Impact of waiting lines on selfservice technology use. International Journal of Contemporary Hospitality Management, (27)6, 1181-1197. https://www.emeraldinsight.com/doi/ full/10.1108/IJCHM-12-2013-0578 https://doi.org/10.1108/IJCHM-12-2013-0578

Kovač, I. i Bajkovec, R. (2015). Customer perception and attitude towards innovations in Croatian retail market. U N. Knego, S. Renko i B. Knežević (Ur.), Trade perspectives 2015.: Innovations in Food Retailing (str. 103-118.). Zagreb, Ekonomski fakultet Sveučilišta u Zagrebu.

Lee, H. J., Cho, H. J., Xu W. i Fairhurst A. (2010). The influence of consumer traits and demographics on intention to use retail self-service checkouts. Marketing Intelligence \& Planning, (28)1, 46-58. https://www.emeraldinsight.com/doi/ abs/10.1108/02634501011014606 https://doi.org/10.1108/02634501011014606

Lee, H. i Yang, K. (2013). Interpersonal service quality, self-service technology (SST) service quality and retail patronage. Journal of Retailing and Consumer Service, (20)1, 51-57. Dostupno na https://www.sciencedirect. com/science/article/pii/S0969698912001257 https://doi.org/10.1016/j.jretconser.2012.10.005

NCR (2014). Self-checkout: A global consumer perspective [online]. Dostupno na: https://www.ncr.com/sites/default/files/white_papers/RET_SCO_wp.pdf (18.06.2018.) 
NV-INCO (2013) Why self-checkout? [online]. Dostupno na: http://www.nv-inco. com/en/contact-information.html (05.05.2018.)

Rogers, Everett M. (1962). Diffusion of Innovations. Free Press of Glencoe, Macmillan Company.

Scherer, A., Wünderlich, N. i Wangenheim, F. (2015). The Value of Self-Service: Long-Term Effects of Technology-Based Self-Service Usage on Customer Retention. MIS Quarterly, (39)1, 177-200. Dostupno na https://misq.org/thevalue-of-self-service-long-term-effects-of-technology-based-self-serviceusage-on-customer-retention.html

Žujo, M. (2012.). Za pet godina polovica blagajni bit će samoposlužna [online]. Zagreb: Jatrgovac. Dostupno na: http://www.poslovni.hr/domace-kompanije/ za-pet-godina-polovica-blagajni-bit-ce-samoposluzna-200926 (30.05.2018.) 
K. MATIĆ, K. PETLJAK, I. ŠTULEC: Prihvaćenost samoposlužnih blagajni prilikom kupovine robe široke potrošnje... EKONOMSKI PREGLED, 70 (2) 301-339 (2019)

\section{Prilog I:}

\section{Podsjetnik za fokus grupu: Prihvaćenost samoposlužnih blagajni među potrošačima u Republici Hrvatskoj}

\section{KORISNICI SAMOPOSLUŽNE BLAGAJNE}

Poštovani, prije svega željela bih Vam se zahvaliti što ste odvojili svoje vrijeme kako biste danas prisustvovali ovoj fokus grupi koja je organizirana u svrhu prikupljanja podataka za istraživački dio diplomskog rada na temu Prihvaćenosti samoposlužnih blagajni među potrošačima u Republici Hrvatskoj.

Budite uvjereni da su sve prikupljene informacije strogo povjerljive i biti će analizirane isključivo na skupnoj razini. Fokus grupa će trajati oko sat i pol te nema pravih/ krivih odgovor. Fokus grupa biti će snimana radi lakše analize dobivenih podataka.

1. Za početak molim Vas da se ukratko predstavite.

2. Možete li za sebe reći da ste društveni tip osobe?

- Volite li komunicirati s ljudima?

- Osjećate li se bolje kada ste sami ili kada ste u društvu?

3. Imate li naviku kupovati u društvu ili više volite kupovati sami? Zašto?

4. Komunicirate li s prodajnim osoblje tijekom kupovine?

- Kada i zašto - u kojim situacijama, komunicirate s prodajnim osobljem?

1. Volite li koristiti tehnologiju - u koje svrhe ju koristite? Pratite li tehnološke inovacije?

2. Što Vam prvo padne na pamet kada čujete pojam samoposlužna tehnologija?

- Koju vrstu samoposlužne tehnologije najčešće koristite u svakodnevnom životu (npr. bankomat, benzinska crpka, automati za plaćanje parkinga...)

3. Smatrate li da Vam je samoposlužna tehnologija olakšala život? Zašto?

4. Povezujete li pojam samoposlužna tehnologija s maloprodajom?

- Što Vam prvo padne na pamet kada pojam samoposlužna tehnologija povežete sa pojmom malopodaja?

1. Jeste li upoznati s pojmom samoposlužne blagajne?

2. Kada i od koga ste prvi put čuli za samoposlužne blagajne?

3. Jeste li ikada koristili samoposlužne blagajne? Gdje, u kojoj prodavaonici?

1. Koji je bio razlog zbog kojeg ste se prvi put odlučili na kupovinu pomoću samoposlužne blagajne?

- Jeste li se teško odlučili na to da isprobate samoposlužnu blagajnu?

- Jeste li ste bili sami ili ste bili s nekim tko je već koristio samoposlužnu blagajnu?

2. Kakav je bio vaš dojam nakon obavljene prve kupovine pomoću samoposlužne blagajne?

- Jeli Vam se kupovna pomoću samoposlužne blagajne činila jednostavna ili komplicirana, zabavna? 


\section{Kupujete li pomoću samoposlužne blagajne prilikom svake kupovine?}

- Ako je odgovor NE, kada najčešće kupujete pomoću samoposlužne blagajne (kada ste u žurbi, kada je red na tradicionalnoj blagajni dug...)?

- Koliko je to vremenski učestalo (mjesečno, tjedno, nekoliko puta godišnje)?

2. Koliki je okvirni iznos vaše košarice kada kupujete pomoću samoposlužne blagajne? (Novčano i/ili broj artikala u košaric)i?

3. Koje skupine proizvoda najčešće kupujete pomoću samoposlužnih blagajni (npr. prehrambene, neprehrambene proizvode)?

4. Koji je razlog zbog kojeg se odlučujete za kupovinu pomoću samoposlužnih blagajni umjesto za kupovinu uz pomoć tradicionalnih blagajni?

5. Ovisi li Vaš odabir predavaonice o tome ima li ona mogućnost kupovati pomoću samoposlužne blagajne?

6. Kada kupujete pomoću samoposlužne tehnologije plaćate li kraticom ili gotovinom?

1. Koje su za Vas prednosti samoposlužne blagajne?

2. Navedite nedostatke samoposlužnih blagajni kojih se možete sjetiti?

- Mislite li da je kupovinom pomoću samoposlužne blagajne olakšana krađa proizvoda?

3. Što mislite kako samoposlužne blagajne utječu na prodajno osoblje?

- Mislite li da će se smanjiti broj prodajnog osoblja zbog pojave samoposlužnih blagajni?

4. Što mislite kakve koristi ima prodavaonica od samoposlužnih blagajni?

1. Jeste li ste ikada imali problema s kupovinom pomoću samoposlužnih blagajni? Kojih?(Molim detaljno prepričavanje događaja)?

- Kako ste se osjećali kada je problem nastao?

- Je li netko od osoblja došao ukloniti problem?

- Koliko je trebalo osoblju da dođe do vas?

- Je li ta osoba znala riješiti problem?

- Koliko je vremenski trebalo da se problem ukloni?

- Prije koliko se to dogodilo?

2. Jeste li i dalje koristite samoposlužnu blagajnu poslije tog događaja?

- Jeste li ste se poslije toga još susretali s tehničkim poteškoćama?

1. Imate li ideju kako unaprijediti samoposlužnu blagajnu kako bi potrošači/Vi bili još zadovoljniji sa njezinom primjenom?

Pitati npr Biste li bi htjeli veći prostor za kupovinu, pakiranje? Personalizirani pristup, mogućnost pamćenja prijašnjih kupnji? Mogućnost kupovine samoposlužnom blagajnom kroz cijelu prodavaonicu (odjel voća, kozmezike...)? Moderniji izgled samoposlužne blagajne? Vizualna signalizacija slobodne blagajne? Da li bi htjeli da su žvakače gume, slatkiši i pića ponuđeni u blizini samoposlužnih blagajni kako bi ih mogli kupiti? Razni popusti/bonus za potrošača koji kupuju uz pomoć samoposlužne blagajne?). 
1. Jeste li koristili još koju vrstu samoposlužne tehnologije u maloprodaji? Koju? Vaša iskustva? Ako niste, da li bi htjeli koristiti još koju vrstu samoposlužnih tehnologija? Koju? Zašto?

1. Jeste li ikad čuli za pojam krađa osobnih podataka?

- Imate li strah od krađe osobnih podataka?

2. Mislite li da može doći do krađe Vaših osobnih podataka ukoliko kupujete uz pomoć samoposlužne blagajne?

Molim Vas, imajte na umu, kao što je već objašnjeno na početku intervjua, ovo je fokus grupa organizirana u svrhu prikupljanja podataka za istraživački dio diplomskog rada na temu Prihvaćenosti samoposlužnih blagajni među potrošačima u Republici Hrvatskoj. Stoga su svi podaci koji su prikupljeni ovim istraživanjem strogo povjerljivi, te će biti analizirani samo na skupnoj razini. Još jednom Vam zahvaljujemo na sudjelovanju u istraživanju, a za kraj Vas molimo da dovršimo intervju sa sociodemografskim podacima.

\begin{tabular}{|l|l|}
\hline Datum fokus grupe: & \\
\hline Broj grupe: & \\
\hline Ime i prezime ispitanika: & \\
\hline Spol: & \\
\hline Dob: & \\
\hline Stupanj obrazovanja: & \\
\hline Zanimanje: & \\
\hline Radni status: & \\
\hline
\end{tabular}




\section{Prilog II.}

Podsjetnik za fokus grupu: Prihvaćenost samoposlužnih blagajni među potrošačima u Republici Hrvatskoj

\section{NEKORISNICI SAMOPOSLUŽNE BLAGAJNE}

Poštovani, prije svega željela bih Vam se zahvaliti što ste odvojili svoje vrijeme kako biste danas prisustvovali ovoj fokus grupi koja je organizirana u svrhu prikupljanja podataka za istraživački dio diplomskog rada na temu Prihvaćenosti samoposlužnih blagajni među potrošačima u Republici Hrvatskoj.

Budite uvjereni da su sve prikupljene informacije strogo povjerljive i biti će analizirane isključivo na skupnoj razini. Fokus grupa će trajati oko sat i pol te nema pravih/krivih odgovor. Fokus grupa biti će snimana radi lakše analize dobivenih podataka.

1. Za početak molim Vas da se ukratko predstavite.

2. Možete li za sebe reći da ste društveni tip osobe?

- Volite li komunicirati s ljudima?

- Osjećate li se bolje kada ste sami ili kada ste u društvu?

3. Imate li naviku kupovati u društvu ili više volite kupovati sami? Zašto?

4. Komunicirate li s prodajnim osoblje tijekom kupovine?

- Kada i zašto - u kojim situacijama, komunicirate s prodajnim osobljem?

1. Volite li koristiti tehnologiju - u koje svrhe ju koristite? Pratite li tehnološke inovacije?

2. Što Vam prvo padne na pamet kada čujete pojam samoposlužna tehnologija?

- Koju vrstu samoposlužne tehnologije najčešće koristite u svakodnevnom životu (npr. bankomat, benzinska crpka, automati za plaćanje parkinga...)

3. Smatrate li mi da vam je samoposlužna tehnologija olakšala život? Zašto?

4. Povezujete li pojam samoposlužna tehnologija s maloprodajom?

- Što Vam prvo padne na pamet kada pojam samoposlužna tehnologija povežete sa pojmom maloprodaja?

1. Jeste li upoznati s pojmom samoposlužne blagajne?

2. Kada i od koga ste prvi put čuli za samoposlužne blagajne?

3. Jeste li ikada koristili samoposlužne blagajne? Gdje, u kojoj prodavaonici?

1. Poznajete li nekoga tko koristi samoposlužnu blagajnu?

- Jeste li bili prisutni kada je netko od Vaših prijatelja/ obitelji kupovao uz pomoć samoposlužne blagajne?

- Kako Vam se u tom trenutku činila kupovina uz pomoć samoposlužnih blagajni (npr.jednostavno, zabavno)?

2. Biste li htjeli samostalno probati kupovati uz pomoć samoposlužne blagajne? 
1. Koji je razlog zbog kojeg se odlučujete za tradicionalnu blagajnu umjesto samoposlužne blagajne?

- Da li zbog toga što niste bili u prilici kupovati (npr. ne kupujete u Konzumu, Plodinama) ili zbog drugog razloga?? Neki od mogućih razloga: Ne znam se služiti samoposlužnom blagajnom, htio sam kupovati uz pomoć samoposlužne blagajne ali su mi upute za korištenje bile nejasne pa sam odustao/-la, straha da ne bih napravio/la grešku koju ne mogu ispraviti, preferiram tradicionalne blagajne, preferiram pomoć od blagajnika za dodatna pitanja koja želim postaviti prije samog plaćanja, smatram da je naplata posao blagajnika, smatram da moji osobni podaci nisu sigurni zbog mogućnosti krađe osobnih podataka?

2. Djeluje li Vam samposlužna blagajna komplicirano za korištenje?

3. Smatrate li da samoposlužna blagajna ima neke nedostatke? Koje?

4. Smatrate li da može doći do pogreške prilikom skeniranja i naplate proizvoda?

5. Smatrate li da je prodajno osoblje dovoljno obučeno za pomoć pri kupovini na samoposlužnoj blagajni?

6. Biste li koristili samoposlužnu blagajnu kada biste znali da je prodajno osoblje uvijek dostupno i u blizini ukoliko dođe do greške tijekom naplate?

1. Što mislite kako samoposlužne blagajne utječu na prodajno osoblje?

- Mislite li da će se smanjiti broj prodajnog osoblja zbog pojave samoposlužnih blagajni?

2. Što mislite kakve koristi ima prodavaonica od samoposlužnih blagajni?

3. Što mislite koje prednosti potrošač može imati korištenjem samoposlužnih blagajni?

1. Biste li koristili samoposlužnu blagajnu kada bi postojala mogućnost dodatne pomoći za kupce koji kupuju prvi put ili kada bi upute za korištenje bile jednostavne?

2. Biste li prisustvovali kratkoj edukaciji o korištenju samoposlužnih blagajni kada bi ona bila organizirana?

- Smatrate li da bi kratka edukacija bila dobar način da se potrošači upoznaju s tom vrstom tehnologije?

3. Biste li koristili samoposlužnu blagajnu kada bih ostvario dodatne pogodnosti (bodove, popuste)?

- Koje pogodnosti bi zanimale Vas kao potrošača?

4. Biste koristili samoposlužnu blagajnu kada bih sa sigurnošću znali da neće doći do greške tijekom njezina korištenja?

5. Postoji li neki drugi razlog zbog kojeg bi se odlučili na kupovinu uz pomoć samoposlužnih blagajni? 
1. Jeste li ikad čuli za pojam krađa osobnih podataka?

- Imate li strah od krađe osobnih podataka?

2. Mislite li da može doći do krađe Vaših osobnih podataka ukoliko kupujete pomoću samoposužne blagajne?

3. Mislite li da je olakšana krađa proizvoda kupovinom uz pomoć samoposlužnih blagajni?

1. Što mislite o drugim samoposlužnim tehnologijama u maloprodaji poput prijenosnih skenera, online prodaji robe široke potrošnje?

- Biste li ih htjeli isprobati neki drugi oblik tehnologije u maloprodaji?

Molim Vas, imajte na umu, kao što je već objašnjeno na početku intervjua, ovo je fokus grupa organizirana u svrhu prikupljanja podataka za istraživački dio diplomskog rada na temu Prihvaćenosti samoposlužnih blagajni među potrošačima u Republici Hrvatskoj. Stoga su svi podaci koji su prikupljeni ovim istraživanjem strogo povjerljivi, te će biti analizirani samo na skupnoj razini. Još jednom Vam zahvaljujemo na sudjelovanju u istraživanju, a za kraj Vas molimo da dovršimo intervju sa sociodemografskim podacima.

\begin{tabular}{|l|l|}
\hline Datum fokus grupe: & \\
\hline Broj grupe: & \\
\hline Ime i prezime ispitanika: & \\
\hline Spol: & \\
\hline Dob: & \\
\hline Stupanj obrazovanja: & \\
\hline Zanimanje: & \\
\hline Radni status: & \\
\hline
\end{tabular}




\title{
ADOPTION OF SELF-CHECKOUTS IN FAST MOVING CONSUMER GOODS PURCHASE AMONG YOUNG CONSUMERS IN CROATIA
}

\begin{abstract}
Summary
Development of information and communication technology has caused major changes in the retail market. Retailers are forced to internationalize their business and introduce innovations in assortment, way of serving, delivery and payment. That creates space, and the need for introducing technological innovations such as self-service technology in retail. Today's consumers are willing to spend less time in store, and for that short time, they require more information about the products they want to buy. The main motive to introduce self-service technology in the store is to provide customers better services and enable easier and faster shopping. The most prevalent form of selfservice technology in stores are self-service cash registers (self-checkouts). Self-checkout is device on which consumers scan the products they want to buy, place them into bags and pay the bill all by themselves. The purpose of the paper is to explore the adoption of self-checkouts in fast moving consumer goods purchase among young consumers in Croatia. In order to detect the acceptance of self-checkout by the Croatian consumers, reasons to use or not use self-checkout and collect ideas for possible improvements, survey was conducted by focus groups. For a better comparison and analysis of the data survey respondents were divided into users and non-users of self-checkouts and all results and conclusions are interpreted on an aggregate level. The issues discussed in the focus group concerned: (1) personality and technological readiness of self-checkout users and nonusers; (2) consumers purchasing frequency and payment method; (3) security of personal data; (4) technical errors; (5) the perceived influence of self-checkout on sales staff reductions; (6) the ability to improve self-checkout and (7) knowledge and usage of other self-service retail technologies. Analysing the results of the research, obtained conclusion is that self-checkouts are not fully accepted by the Croatian consumers and that they consider it as auxiliary register. One of the main reasons for unacceptance of self-checkouts is frequent technical failures which occur and because of that there is large space for improvement of self-checkout technology. The main limitation of the conducted research is the limitation of the research method itself. With a desire of deeper understanding and achievement of research goals, it is proposed in the future to conduct a quantitative research in shops that have self-checkouts. The scientific contribution and value of research is reflected in the deep exploration and analysis of the acceptance of self-checkouts for the purchase of fast moving consumer goods among young consumers in Croatia.
\end{abstract}

Key words: retail, self-service technology, self-checkouts, self-checkout users, self-checkout non-users, young consumers, focus group. 